\title{
Impacts of Western Area Power Administration's Power Marketing Alternatives on Utility Demand-Side Management and Conservation and Renewable Energy Programs
}

Decision and Information Sciences Division

Argonne National Laboratory

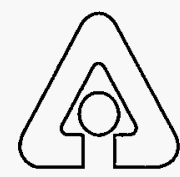

Operated by The University of Chicago, under Contract W-31-109-Eng-38, for the

United States Department of Energy 


\section{Argonne National Laboratory}

Argonne National Laboratory, with facilities in the states of Illinois and Idaho, is owned by the United States Government, and operated by the University of Chicago under the provisions of a contract with the Department of Energy.

This technical memo is a product of Argonne's Decision and Information Sciences (DIS) Division. For information on the division's scientific and engineering activities, contact:

Director, Decision and Information

Sciences Division

Argonne National Laboratory

Argonne, Illinois 60439-4815

Telephone (708) 252-5464

Presented in this technical memo are preliminary results of ongoing work or work that is more limited in scope and depth than that described in formal reports issued by the DIS Division.

Publishing support services were provided by Argonne's Information and Publishing Division (for more information, see IPD's home page: http://www.ipd.an!.gov/).

\section{Disclaimer}

This report was prepared as an account of work sponsored by an agency of the United States Government. Neither the United States Government nor any agency thereof, nor any of their employees, makes any warranty, express or implied, or assumes any legal liability or responsibility for the accuracy, completeness, or usefulness of any information, apparatus, product, or process disclosed, or represents that its use would not infringe privately owned rights. Reference herein to any specific commercial product, process, or service by trade name, trademark, manufacturer, or othenwise, does not necessarily constitute or imply its endorsement, recommendation, or favoring by the United States Government or any agency thereof. The views and opinions of authors expressed herein do not necessarily state or reflect those of the United States Government or any agency thereof.

Reproduced directly from the best available copy.

Available to DOE and DOE contractors from the Office of Scientific and Technical Information, P.O. Box 62, Oak Ridge, TN 37831; prices available from (615) 576-8401.

Available to the public from the National Technical Information Service, U.S. Department of Commerce, 5285 Port Royal Road, Springfield, VA 22161. 


\section{Impacts of Western Area Power Administration's Power Marketing Alternatives on Utility Demand-Side Management and Conservation and Renewable Energy Programs}

by J.D. Cavallo, M.F. Germer, and M.M. Tompkins

Policy and Economic Analysis Group,

Decision and Information Sciences Division,

Argonne National Laboratory, 9700 South Cass Avenue, Argonne, Illinois 60439

March 1995

Work sponsored by United States Department of Energy,

Western Area Power Administration 
This report is printed on recycled paper. 


\section{FOREWORD}

This report is one of a series of technical memorandums prepared to support an environmental impact statement (EIS) on power marketing prepared by Argonne National Laboratory for the U.S. Department of Energy's Western Area Power Administration (Western). Western markets electricity produced at hydroelectric facilities operated by the Bureau of Reclamation. The facilities are known collectively as the Salt Lake City Area Integrated Projects (SLCA/IP) and include dams equipped for power generation on the Colorado, Green, Gunnison, and Rio Grande rivers and on Plateau Creek in the states of Arizona, Colorado, New Mexico, Utah, and Wyoming.

Western proposes to establish a level of commitment (sales) of long-term firm electrical capacity and energy from the SLCA/IP hydroelectric power plants; the impacts of this proposed action are evaluated in the EIS. Of the SLCA/IP facilities, only the Glen Canyon Dam, Flaming Gorge Dam, and Aspinall Unit (which includes Blue Mesa, Morrow Point, and Crystal dams) are influenced by Western's power scheduling and transmission decisions. For this reason, the impacts of hydropower operations at these three facilities were examined in the EIS.

The technical memorandums present detailed findings of studies conducted by Argonne National Laboratory specifically for the EIS. These studies are summarized in the EIS, and the results were used to assess environmental impacts related to alternative commitment levels. Technical memorandums were prepared on a number of socioeconomic and natural resource topics. Staff members of Argonne National Laboratory's Decision and Information Sciences Division and Environmental Assessment Division prepared these technical memorandums and the EIS as part of a joint effort managed by the Environmental Assessment Division. 


\section{CONTENTS}

FOREWORD $\ldots \ldots \ldots \ldots \ldots \ldots \ldots \ldots \ldots \ldots \ldots \ldots \ldots \ldots \ldots \ldots \ldots \ldots \ldots$ iii

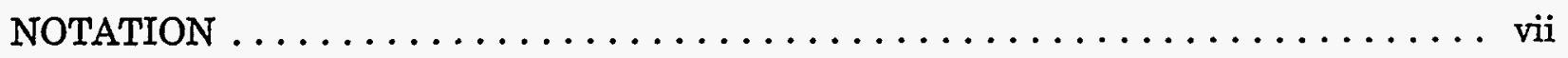

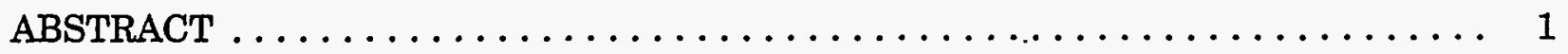

SUMMARY $\ldots \ldots \ldots \ldots \ldots \ldots \ldots \ldots \ldots \ldots \ldots \ldots \ldots \ldots \ldots \ldots \ldots \ldots \ldots \ldots \ldots \ldots$

1 INTRODUCTION AND BACKGROUND $\ldots \ldots \ldots \ldots \ldots \ldots \ldots \ldots \ldots$

2 BASIC TERMS, TOOLS, AND INFORMATION SOURCES $\ldots \ldots \ldots \ldots \ldots \ldots$

3 METHOD FOR ESTIMATING REDUCTIONS DUE TO

CURRENT C\&RE ACTIVITIES $\ldots \ldots \ldots \ldots \ldots \ldots \ldots \ldots \ldots \ldots \ldots$

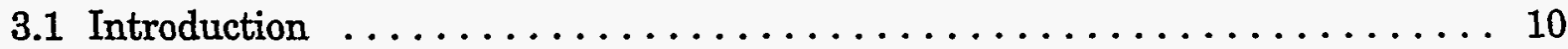

3.2 Identifying Currently Operating C\&RE Activities $\ldots \ldots \ldots \ldots \ldots \ldots 11$

3.3 Estimating the Reductions from Currently Operating C\&RE Activities ..... 16

3.4 Identifying C\&RE Activities Affected by the EIS Alternatives $\ldots \ldots \ldots \ldots 22$

3.5 Modeling Potentially Affected C\&RE Activities $\ldots \ldots \ldots \ldots \ldots \ldots \ldots$

4 FORECASTS OF THE COSTS AND REDUCTIONS FROM COST-EFFECTIVE DEMAND-SIDE MANAGEMENT PROGRAMS . . . . . . . 24

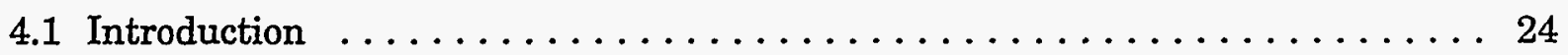

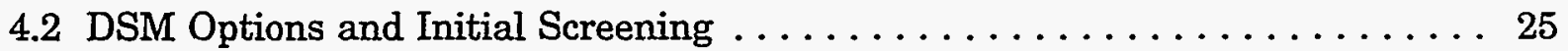

4.3 DSM Program Cost and Participation Estimates ............... 25

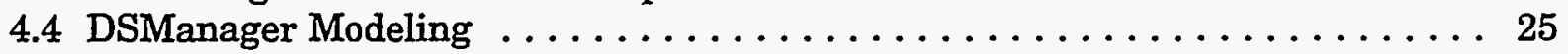

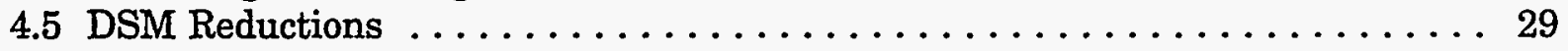

5 CONCLUSIONS AND DISCUSSION $\ldots \ldots \ldots \ldots \ldots \ldots \ldots \ldots \ldots \ldots \ldots \ldots$

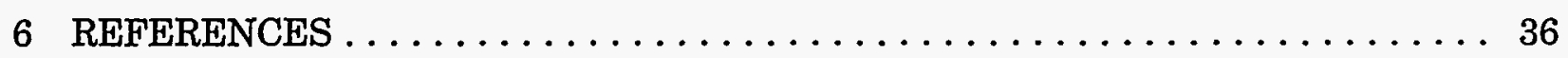

APPENDIX: $\begin{aligned} \text { Program Summary Sheets for the Demand-Side } \\ \text { Management Programs } \ldots \ldots \ldots \ldots \ldots \ldots \ldots \ldots \ldots \ldots\end{aligned}$

\section{FIGURES}

1 Marginal Energy Costs as Forecast by PACE for January $1998 \ldots \ldots \ldots \ldots \ldots 27$

2 Marginal Energy Costs as Forecast by PACE for June $1998 \ldots \ldots \ldots \ldots \ldots \ldots 27$ 


\section{TABLES}

1 G\&AC Customer C\&RE Activity List $\ldots \ldots \ldots \ldots \ldots \ldots \ldots \ldots \ldots \ldots \ldots \ldots \ldots \ldots \ldots$

2 Frequency Distribution of C\&RE Activities by Major Activity Type $\ldots \ldots \ldots \ldots$

3 Percentage Distribution of C\&RE Activities by Major Activity Type $\ldots \ldots \ldots \ldots 15$

4 Activities with Highest Customer Participation Rates $\ldots \ldots \ldots \ldots \ldots \ldots$

5 DSManager Results for Prototypical Utility: Ratios of Present Values

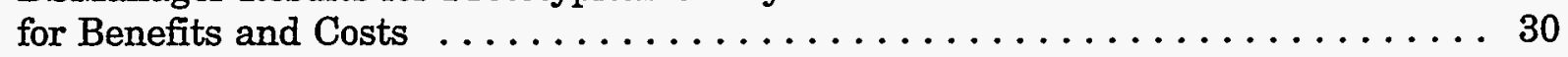

6 Description of DSM Programs $\ldots \ldots \ldots \ldots \ldots \ldots \ldots \ldots \ldots \ldots \ldots \ldots \ldots \ldots \ldots \ldots$

7 Forecasted DSM Reductions - Colorado Springs Municipal Utility ........ 32 


\section{NOTATION}

\section{ACRONYMS, INITIALISMS, AND ABBREVIATIONS}

$\begin{array}{ll}\text { ANL } & \text { Argonne National Laboratory } \\ \text { C\&RE } & \text { conservation and renewable energy } \\ \text { C\&RE-SLC } & \text { Conservation and Renewable Energy - Salt Lake City } \\ \text { CACS } & \text { Commercial and Apartment Conservation Service } \\ \text { DLC } & \text { direct load control } \\ \text { DOE } & \text { U.S. Department of Energy } \\ \text { DSM } & \text { demand-side management } \\ \text { EIS } & \text { environmental impact statement } \\ \text { EPAMP } & \text { Energy Planning and Management Program } \\ \text { EPRI } & \text { Electric Power Research Institute } \\ \text { G\&AC } & \text { guidelines and acceptance criteria } \\ \text { IRP } & \text { integrated resource plan } \\ \text { PACE } & \text { Production and Capacity Expansion } \\ \text { PEPCO } & \text { Potomac Electric Power Company } \\ \text { RCS } & \text { Residential Conservation Program } \\ \text { RDF } & \text { refuse-derived fuels } \\ \text { RIM } & \text { ratepayer impact measure } \\ \text { SERI } & \text { Solar Energy Research Institute } \\ \text { SO } & \text { sulfur dioxide } \\ \text { SURIS } & \text { Survey Information System } \\ \text { TRC } & \text { total resource cost } \\ \text { Western } & \text { Western Area Power Administration }\end{array}$

\section{UNITS OF MEASURE}

$\begin{array}{ll}\text { acre-ft/yr } & \text { acre-feet per year } \\ \mathrm{d} & \text { days } \\ \mathrm{ft} & \text { feet } \\ \mathrm{ft}^{2} & \text { square feet } \\ \mathrm{GWh} & \text { gigawatt-hours } \\ \mathrm{h} & \text { hours } \\ \mathrm{kW} & \text { kilowatts } \\ \mathrm{kWh} & \text { kilowatt-hours } \\ \mathrm{lb} & \text { pounds } \\ \mathrm{MW} & \text { megawatts } \\ \mathrm{MWh} & \text { megawatt-hours } \\ \mathrm{psi} & \text { pounds per square inch } \\ \mathrm{W} & \text { watts } \\ \mathrm{Wh} & \text { watt-hours } \\ \mathrm{yr} & \text { years }\end{array}$




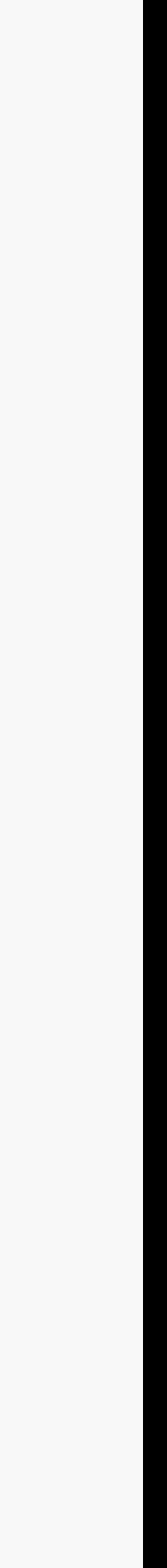




\title{
IMPACTS OF WESTERN AREA POWER ADMINISTRATION'S \\ POWER MARKETING ALTERNATIVES \\ ON UTILITY DEMAND-SIDE MANAGEMENT AND \\ CONSERVATION AND RENEWABLE ENERGY PROGRAMS
}

by

\author{
J.D. Cavallo, M.F. Germer, and M.M. Tompkins
}

\begin{abstract}
The Western Area Power Administration (Western) requires all of its long-term firm power customers to implement programs that promote the conservation of electric energy or facilitate the use of renewable energy resources. Western has also proposed that all customers develop integrated resource plans that include cost-effective demand-side management programs. As part of the preparation of Western's Electric Power Marketing Environmental Impact Statement, Argonne National Laboratory (ANL) developed estimates of the reductions in energy demand resulting from Western's conservation and renewable energy activities in its Salt Lake City Area Office. ANL has also estimated the energy-demand reductions from cost-effective, demand-side management programs that could be included in the integrated resource plans of the customers served by Western's Salt Lake City Area Office. The results of this study have been used to adjust the expected hourly demand for Western's major systems in the Salt Lake City Area. The expected hourly demand served as the basis for capacity expansion plans developed with ANL's Production and Capacity Expansion (PACE) model.
\end{abstract}

\section{SUMMARY}

The Western Area Power Administration (Western) has proposed to change the electrical capacity and energy commitment levels that it offers to its long-term firm power customers of the Salt Lake City Area. Most of Western's customers are electric cooperatives, municipal electric utilities, and federal agencies. These customers receive a percentage of their electric power needs from Western's Salt Lake City Area Integrated Project hydroelectric power plants. If the power marketing changes proposed by Western are implemented, significant impacts are possible on the environment of. the Upper Colorado River and its tributaries. To investigate the possible environmental consequences of the proposed power marketing changes, Argonne National Laboratory is preparing an environmental impact statement (EIS) on the proposed action and significant alternative actions. 
The study reported here examines whether there will be significant impacts from the proposed change on the operation of Western conservation and renewable energy (C\&RE) activities. Western's customers are currently required to implement from three to five C\&RE activities in an effort to conserve energy and maintain environmental quality. This study also provides input to the capacity expansion modeling conducted as part of the EIS and researches the economic basis of reducing energy and peak load requirements through demand-side management (DSM) programs. DSM programs can offset the need for the construction or expansion of generating units by influencing the demands placed on the electric generating system.

The analysis has created a comprehensive database of the currently operating C\&RE activities implemented by Western's customers in the Salt Lake City Area. A majority of the C\&RE activities are energy consumption efficiency measures similar to the DSM programs operated at many major electric utilities throughout the country. An estimation of the peak load and energy sales reductions associated with the C\&RE activities currently operating in the Salt Lake City Area finds that the C\&RE activities reduce peak load by approximately $3 \%$ and reduce energy sales by approximately $1.8 \%$. This analysis shows that there will be no significant impact on the currently operating C\&RE activities if Western implements either the proposed action or any other EIS alternatives.

This analysis also examined the opportunities for cost-effective DSM programs to fit into the capacity expansion plans of the major systems in Western's Salt Lake City Area. Structured as a bottom-up approach, the study identified 18 potentially economical DSM programs; developed cost estimates for each program; and modeled the DSM programs by using the computer simulation tool, DSManager, developed by the Electric Power Research Institute. The analysis found that cost-effective DSM programs can reduce peak load by approximately $1.4 \%$ in the outer years of the planning horizon (1993-2012) and can reduce energy sales by approximately $1.6 \%$ in the same years. There was no significant difference between the peak load or energy sales reductions derived for the several EIS alternatives studied. The estimated reductions from cost-effective DSM were used to reduce the load requirements of the supply expansion modeled by ANL's Power Systems Task Group. 


\section{INTRODUCTION AND BACKGROUND}

The Western Area Power Administration (Western) has proposed to change the electrical capacity and energy commitment levels that it offers to its long-term firm power customers of the Salt Lake City Area. These proposed changes in capacity and energy commitment levels have been under development for more than 10 years and represent a strategy for marketing hydroelectric power that will enhance the efficiency with which electric power is used and will provide public power to the areas of growing demand. Because the changes could have significant impacts on the environment, the Electric Power Marketing Environmental Impact Statement (EIS) is being prepared on the proposed changes in power commitment levels.

Because many environmentalists consider soft energy paths, such as those included in Western's conservation and renewable energy (C\&RE) activities, as a likely means of avoiding the environmental consequences of conventional power generation, it is important to examine the possible impact that the power marketing proposals may have on the C\&RE activities. For instance, if the proposed changes reduced or increased the incentives for operating C\&RE activities by Western's customers, environmental impacts could indirectly result from the proposed marketing strategy.

Additionally, an important part of the Electric Power Marketing Program EIS is the evaluation of the possible future environmental impacts resulting from an expansion of the conventional power supply resources as a result of the growth in electricity demand in the region. Argonne National Laboratory (ANL) has simulated the response of Western's customers in the Salt Lake City Area to the growth in demand by developing integrated resource plans (IRPs) for the major systems in the region. As part of the IRPs, ANL has examined the opportunities for reducing the need of the customers to add supply-side resources through the use of demand-side management (DSM) programs.

The research reported here studies both Western's currently operating C\&RE activities and the cost-effective DSM programs that can enter into the customer's expansion plans. There is a great deal of overlap between the two areas of research because the majority of Western's C\&RE activities can be considered DSM programs. However, because the goals of the two areas of research are different, the research has been divided. Section 3 examines Western's C\&RE activities with the goal of evaluating the impacts of the alternative EIS power marketing plans on the current C\&RE activities. Estimates are developed for the energy sales and peak load reductions of the C\&RE activities in the Salt Lake City Area. Section 4 identifies potentially economical DSM programs for the region and computes which DSM programs are cost-effective, given the forecasted marginal system energy costs of an actual operating utility in the region. A bottom-up approach is used to identify cost-effective DSM programs by costing out and modeling the interactions of individual DSM programs with the supply side of the utility. The hourly reductions associated with the cost-effective DSM programs are subtracted from the forecasted supply requirements that were used as the basis of the capacity expansion planning. 
Preceding the technical details of the study's methods, Section 2 offers definitions of terms frequently used in this analysis as well as a discussion of some of the important tools used. Though it is unlikely that the brief discussion will provide an education to one who has not worked in the field, it is hoped that enough information is provided for the reader to understand the meaning of terms in this report. 


\section{BASIC TERMS, TOOLS, AND INFORMATION SOURCES}

In recent years, public utilities across the United States have extended their abilities to provide reliable and low-cost service to energy end-users by developing DSM programs. The greatest use of DSM programs in recent years has been in electric utilities, though gas utilities also have begun to implement DSM plans and programs. Approximately 500 electric utilities in the U.S. currently are sponsoring more than 1,300 DSM programs (EPRI 1990a, p.1), and a majority of states require electric utilities to formulate periodic IRPs that incorporate energy conservation and peak-load management options in utility expansion plans whenever the marginal costs of such options are lower than the marginal costs of supply-side alternatives.

DSM programs are activities undertaken by utilities to alter the usage patterns of their customers. Two examples of such programs are direct control of residential air conditioners by the electric utility on days of peak load and utility incentives to install energy-efficient lighting. The benefits of such DSM programs are potentially significant; however, to generate the benefits, strategic and systemwide planning is required. The direct control of residential air conditioners, for instance, can offset the need for the construction of expensive peaking plants without significantly reducing utility revenues. Reducing air conditioning load can be important because residential air conditioners consume as much as $45 \%$ of the residential summer peak load in American metropolitan areas. Utility incentives for investments in energy-efficient lighting systems - if the investment would not otherwise occur - can reduce sulfur dioxide $\left(\mathrm{SO}_{2}\right)$ pollution because fewer coal-fired plants need to be operated. Electricity demand for lighting has been estimated to be approximately $20 \%$ of total annual electricity demand.

IRPs can provide a mechanism for capturing the potential benefits of DSM programs while meeting load and reliability requirements. An IRP's key characteristic is the explicit consideration of peak-load management and energy conservation programs as alternatives to power generating facilities. IRPs differ from older methods of utility planning in several fundamental ways. First, IRPs recognize that electricity is not consumed for its own sake but for the heating, cooling, lighting, or other services the energy produces when used with some capital or durable good. Accordingly, IRPs can incorporate the knowledge and experience of both utility engineers and economists in the design and operation of a range of technologies that use electricity. Second, IRPs acknowledge that energy consumers face market barriers that prevent or unduly discourage them from making investments that would permit more efficient use of electricity or gas. The utility may pursue a larger role than just supplying energy by assisting consumers in conserving energy resources. For instance, providing and installing electric-water-heater blankets for older or income-constrained customers can reduce or postpone the need for construction of baseload power plants. Finally, IRPs seek to balance DSM programs with the conventional supply-side options of capacity expansion. Such a balance is not found by simply choosing DSM programs, reducing the load forecast by the energy savings of the programs, and subsequently planning to meet the net load growth with capacity expansion only. A balanced plan permits demand and supply options to compete for 
a place in the utility's portfolio of DSM programs and plant capacity. Others (e.g., Chema 1990, pp. 11-16) have argued for the inclusion of DSM programs in utility plans for different reasons, but the equal treatment of DSM and supply-side options is the essential element in the application of scientific and unbiased methods in utility planning. The features that distinguish IRP from traditional utility planning aim at finding the least costly method of satisfying customer needs for energy services.

DSM programs can be classified into four categories: peak shaving, load shifting, valley filling, and energy conserving (Bernard et al. 1990, pp. 261-292). Each class of programs can fill a specific need in a utility's plans, and no single DSM program is likely to entirely replace a major power plant; however, DSM plans woven carefully together can conserve substantial amounts of energy and capacity. Estimates of the energy saving, in fact, have ranged from 24 to $75 \%$ of electricity demand (GAO 1991, p. 10). A brief description of the four categories of DSM programs is given below with examples of individual programs that can fit into the categories.

Peak-shaving DSM programs are often most attractive to utilities. By reducing the peak, utilities can eliminate what is often the most costly portion of its annual load. Utilities need to build their systems to meet their peak load, and yet a utility's pricing structure almost inevitably connects revenues most directly to its monthly and annual energy sales. Peak-load management programs reduce the utility's capacity requirements without substantially reducing monthly energy sales because only a few hours of load are affected. Examples of peak-load shaving programs are (1) special lower demand and energy rates for industrial interruptible service and (2) billing credits for commitments by commercial and industrial customers to reduce load by specified amounts at the utility's request. Because many commercial and industrial customers have fixed working hours or routine energy usage patterns, there is no sizable bounce-back or payback effect after the control period. A payback effect occurs when the customer load partially compensates for the control period by growing immediately after the period of control. Such commercial and industrial peak-load management programs usually are organized directly by the utility. Some innovative organizations have appeared, however, through which the load management program is developed outside of the utility as a cooperative venture. One interesting example of this cooperative structure is the Commonwealth Edison Energy Cooperative in Chicago, of which ANL is a member and participant.

Load shifting is a second general type of DSM program. This class of programs includes time-of-use pricing, discounts on the purchase of appliance timers, incentives for the installation of cool storage systems, and direct load control of residential air conditioners and water heaters. Programs of this type shift load from hours of peak demand (usually in the early and middle afternoon) to hours of low demand. Most of these programs reduce both peak-load and overall energy sales, but some do not. Direct load control of residential air conditioners, for instance, reduces peak load because the program is operated only during peak periods on hot summer days. Energy sales are not greatly affected because the programs only operate for a few hours during the year, and the payback effect after the control period only partially recovers the lost load during the control period. In contrast, the 
installation of cool storage systems will increase overall energy sales while reducing peak demand because the storage of cooling capacity in water or ice is not $100 \%$ efficient.

Valley filling is a DSM approach that stimulates the utility's demand during off-peak hours and nonpeak seasons (usually in the very early morning hours and the spring and autumn seasons). One example of valley filling is paying incentives for the purchase of efficient electric heat pumps or gas absorption air conditioners in regions with electric utilities that have strong summer peak loads. A second example is encouraging electric vehicles as replacements for gasoline-engine cars. Valley filling can lead to increased efficiencies if it raises the load factors of electric and gas utilities and enables the utilities to use more economical generating or supply technologies. In other words, if an electric utility could change its capacity mix to reduce the usage of high-cost peaking and cycling plants and increase the usage of efficient baseload plants, overall system efficiency could be improved. Commonly, utilities executives are as fond of valley filling DSM programs as conservationists are wary of them. Perhaps the first DSM program was that of Thomas Edison in the 1890s. Edison hired people to promote the use of electric motors and other daytime uses of electricity to counterbalance the nighttime lighting load (Lamarre 1991, pp. 5-15).

Energy-conserving DSM programs are activities undertaken by the utility to strictly reduce energy usage. These programs do not reduce load in some hours and add load in other hours, as load shifting programs will. Important examples of this class of programs include incentives for energy-efficient lighting, replacement of incandescent bulbs with compact fluorescent bulbs, free energy audits, low-interest loan programs for weatherization, and incentives for the purchase of high-efficiency appliances. Energy conservation DSM programs are not likely to be in the best financial interest of a utility unless incentives to the utility are given by regulatory bodies to compensate for revenues lost through DSM. In recent years, a number of states have encouraged utilities to offer energy conserving DSM programs through such incentive methods. In the future, conservation may be found to serve some utilities' financial interest as clean air requirements force electric utilities to place a high value on reductions in pollution from baseload fossil fuel plants (Bernard 1990, pp. 261-292).

These four broad categories of DSM programs must not be seen as containing homogeneous programs that can be incorporated into a utility's IRP as four simple equations. The many DSM measures and programs that are classified in the four categories contain unique characteristics. In fact, because DSM programs fit between end-user behavior patterns and day-to-day generating unit operations, a DSM program can function very differently in one utility from the way it does in another. The Electric Power Research Institute (EPRI) has surveyed electric utilities across the country to identify the types of DSM programs in operation and to examine the differences in operations across utilities. The survey information collected by EPRI has been compiled in three publications for residential DSM programs (EPRI 1989), commercial programs (EPRI 1992), and industrial programs (EPRI 1991a). These data and additional information appear in a computer database developed by EPRI (1991b). These sources provided an important information for the study reported here. 
Because individual DSM programs differ among utilities, the analysis in this report took a bottom-up approach that first identified potentially cost-effective DSM programs and then modeled the programs to examine how the programs would operate within the utility's system. The modeling tool used to simulate the operation of the individual DSM programs was DSManager, an EPRI product widely recognized as a state-of-the-art DSM evaluation model. DSManager has been distributed to more than 100 utilities.

DSManager relies on the hourly demand differential created by a candidate DSM measure to estimate the relative costs and benefits of the measure. DSManager automatically calculates all five standard economic tests that utilities and commissions tend to use in assessing the desirability of potential DSM measures. The five tests are defined as follows (test results for each DSM program modeled are presented in Section 4.5 in Table 5):

1. The Participant Test measures the ratio of costs and benefits of a DSM program from the participant's point of view. Costs typically involve an initial investment in a higher-efficiency appliance, while benefits often include rebates paid by the utility, as well as reduced electric bills.

2. The Utility Test measures the effects of a DSM measure or program from the utilitys point of view. Costs typically involve the rebates paid to customers to encourage some desired change in energy consumption, whereas the benefits include operating cost savings and avoided capital expenditures. This test typically disallows any effort to increase sales in off-peak hours because revenues from increased off-peak sales are often less than the associated increases in operating costs.

3. The Ratepayer Impact Measure (RIM) Test is used to determine the impact of a specific DSM program on average electric rates. This test is favored by many utilities, but conservationists dislike it because it tends to eliminate pure conservation measures. It does so because reductions in energy use, given constant utility revenue requirements, result in increases in rates.

4. The Total Resource Cost (TRC) Test combines the Participant and Utility tests and is designed to take into account all costs for DSM program implementation, whether incurred by the utility or by the participating customer. Likewise, this test accounts for all benefits enjoyed by both parties.

5. The Societal Test is a variation of the TRC Test; the only difference is that economic externalities (properly quantified) are added to the costs used in the TRC Test.

The TRC Test was chosen to determine the inclusion or exclusion of DSM programs from the capacity expansion plans in the Western EIS. The TRC was the most comprehensive test of the overall benefits and costs to the utility and its end-users. The 
Societal Test would be a more comprehensive measure of well-being but could not be implemented because environmental impacts were not available when the DSM analysis was conducted

The computational methods used in DSManager as well as the required inputs are discussed in detail in the program documentation (EPRI 1991c) and are not repeated here. However, note that DSManager serves well as a tool to permit supply-side resources and DSM programs to compete for places in expansion plans. It has been used in that manner for this analysis. 


\section{METHOD FOR ESTIMATING REDUCTIONS DUE TO CURRENT C\&RE ACTIVITIES}

\subsection{INTRODUCTION}

The purpose of the C\&RE analysis is to evaluate the impacts of the alternative marketing plans studied in this EIS on current C\&RE activities. All long-term firm power customers of Western are required to implement at least three and as many as five C\&RE activities, depending on customer size. Western has designed its C\&RE requirements to promote the efficient use of energy and to facilitate the use of renewable energy sources. Some activities are designed to improve energy consumption efficiency or reduce peak load. Other activities are developed to use renewable sources of energy supply or to cogenerate electricity with the use of energy for some other purpose.

Western is preparing the Energy Planning and Management Program (EPAMP) EIS (Western 1991) on its proposal to replace its current conservation and renewable energy program with a two-part program. The replacement program would determine what percentage of long-term allocations of Western's hydroelectric resources would be extended to Western's customers at the end of their existing contract terms (called the power marketing initiative). It would also encourage long-term energy management planning by Western's firm power customers. Western will evaluate the application of the power marketing initiative to the SLCA/IP after the Power Marketing EIS is completed.

The source of the requirement that Western's customers implement C\&RE activities is the guidelines and acceptance criteria (G\&AC) published in the Federal Register on November 13, 1981 (46 FR 56140). The G\&AC was amended in 1985 (50 FR 33892), after legislation reinforcing the C\&RE program was passed as part of Title II of the Hoover Power Plant Act. Customers that do not comply with the G\&AC are subject to a penalty - a $10 \%$ reduction in the Western power-contract commitment.

Although cooperative or municipal utilities could adopt new C\&RE activities or expand participation in current activities for a variety of reasons such as reduced dependence on outside power or an improved global environment, the analysis developed for this Power Marketing EIS postulates that additional C\&RE activities would only be implemented if the utilities found economic advantage in such new activities. Similarly, for this EIS, it is assumed that currently operating C\&RE activities will not be expanded if the costs of such expansion outweigh the benefits. Such expansions are analyzed as part of the DSM study described in Section 4. On the basis of the assumption that only cost-effective activities will be implemented or expanded, C\&RE activities will be impacted by alternative marketing plans through the economic consequences of C\&RE activities as economical substitutes for power purchased from Western or produced directly by the utilities.

The method for the analysis of the C\&RE activities was divided into four parts: (1) identify the currently operating C\&RE activities of each utility, (2) estimate the energy and peak demand reductions of each activity, (3) identify the activities that would likely be 
affected by shifts from the baseline alternative to a different marketing plan, and (4) model the potentially affected activities under the marginal system costs of the alternative that shows the greatest deviation from the baseline.

\subsection{IDENTIFYING CURRENTLY OPERATING C\&RE ACTIVITIES}

The initial step in the C\&RE analysis was to identify the currently operating C\&RE activities. To this end, analysts developed an extensive database from the C\&RE files of Western's Salt Lake City Area Office. The database, Conservation and Renewable EnergySalt Lake City (C\&RE-SLC), is described in an ANL technical memorandum (Cavallo et al. 1992). The database contains 1,242 entries and tracks the development of $C \& R E$ activities at the cooperatives and municipals served by Western's Salt Lake City Area Office. Extensive descriptions of individual activities are given in the database along with the size and type of utility employing the activity.

The information included in the database came from customer planning documents in the files of the Salt Lake City Area Office of Western. Each of Western's customers is required to submit an update to its $C \& R E$ plan every two years. Customers also are required to determine goals for each of their C\&RE activities and to evaluate how close they have come to meeting the goals. The announcement in the Federal Register (50 FR 33897), however, states that (1) Western may not approve a customer program that offers a low energy savings and (2) customers must commit resources and develop a reasonable organizational effort to demonstrate a good faith effort to reach the stated goals.

The C\&RE database was organized to accurately represent the information included in the planning documents submitted by Western customers. For accurate representation, the database follows the same structure as the program files found at Western's Salt Lake City Area Office. The most important parts of the database are the identification of activity type, the goal each utility has for its activities, and the description of the activity. Various other items in the database permit the activities to be sorted so that relevant combinations of database records can be searched, combined, or examined for research and analysis.

Each activity is categorized by type. The codes for the activities were established in the G\&AC for the C\&RE Program (50 FR 33892) in 1985. The codes are for the specific activities that Western's customers can choose in order to fulfill their C\&RE requirement. Table 1 provides the codes and activity types. Each code has an initial capital letter identifying its category. After the category letter, a number (or a number followed by a lowercase letter) indicates a specific activity within the category. For example, category $F$ contains all activities that improve production efficiency, and activity F1 specifies improved generation equipment efficiency.

Each utility is required to submit a goal for each activity. Western requests that the goals be measurable; that is, they ask that quantities be specified and results be quantifiable. Few planning documents have such goals, however. The goals that appear in the database 
TABLE 1 G\&AC Customer C\&RE Activity List

\begin{tabular}{|c|c|}
\hline $\begin{array}{l}\text { Code } \\
\text { Activity }\end{array}$ & Description \\
\hline \multicolumn{2}{|c|}{ Category A - Energy Consumption Efficiency Improvements } \\
\hline A1 & Building energy conservation programs that may include activities such as: \\
\hline Ala & Boiler, furnace, air conditioner retrofitting, including dual fuel \\
\hline Alb & Weatherization/insulation \\
\hline Alc & Storm windows/doors \\
\hline Ald & Insulation of air ducts, boilers, pipes, etc. \\
\hline Ale & Heat reflective/absorbing window or floor materials, water heaters, etc. \\
\hline Alf & Clock thermostats and equipment/system timers \\
\hline Alg & Electrical or mechanical ignition systems \\
\hline Alh & Heat pumps \\
\hline A2 & Energy audits \\
\hline A3 & Installation of energy storage equipment; thermal energy storage \\
\hline A4 & Information dissemination programs \\
\hline A5 & Economic assessment studies for conservation activities \\
\hline A6 & Development of energy efficiency awards programs \\
\hline A7 & Building plan review/service programs \\
\hline A8 & Loan arrangements or assistance \\
\hline A9 & Conservation demonstration projects \\
\hline A10 & Installation arrangements/assistance \\
\hline All & Attendance at conservation and/or renewable energy training \\
\hline A12 & Technical assistance to end-users \\
\hline A13 & Listing services for suppliers/lenders \\
\hline A14 & Customer in-house program activities \\
\hline A15 & Use of infrared heat detection equipment \\
\hline A16 & Home energy rating systems development \\
\hline A17 & $\begin{array}{l}\text { Computer programs development for conservation/energy efficiencies or } \\
\text { community energy management strategies }\end{array}$ \\
\hline A18 & Energy-efficient lighting conversions \\
\hline A19 & Equipment inspection programs \\
\hline A20 & Improvement of operating procedures to maximize efficiencies \\
\hline A21 & Building code requirements \\
\hline A22 & Use of blower doors \\
\hline
\end{tabular}

\section{Category B - Renewable Energy Activities}

B1 Solar thermal/photovoltaic projects

B2 Solar pond projects

B3 Daylighting technologies

B4 Active solar installations

B5 Ocean thermal gradients/tidal power

B6 Passive solar installations

B7 Small/large-scale wind turbine installations

B8 Biomass/refuse-derived fuels (RDF) projects

B9 Geothermal projects

B10 Wind measurement/recording equipment 
TABLE 1 (Cont.)

Code

Activity

Description

B11 Economic assessment studies for renewable resources

B12 Interconnection services to renewable resource facilities

B13 Cooperative renewable resource development projects

B14 Fuel cell projects

B15 Small-scale hydro projects

Category C - Load Management Techniques

C1 Load management devices/systems

C2 Rephasing operations to reduce energy consumption

C3 Demand control techniques and equipment

C4 Consumer education

C5 Cable television metering systems

C6 Smart meters or automated equipment

C7 Data management analyses or interpretation

C8 Time-of-use meters

C9 Energy usage patterns analyses

Category D - Cogeneration

D1 Cogeneration projects

D2 Scrap and waste reclamation

D3 Waste heat recovery

D4 District heating

D5 Greenhouse applications

D6 Utility/industrial interfaces as related to cogeneration technologies

Category $E-$ Rate Design Improvements

E1 Cost of service pricing

E2 Elimination of declining block rates

E3 Time-of-day rates

E4 Seasonal rates

E5 Interruptible rates

E6 Purchase of customer-generated renewable energy

E7 Sale and purchase of surplus power to displace petroleum fuels (resource coordination)

E8 Rate restructuring/adjustments

\section{Category $F$ - Production Efficiency Improvements}

F1 Improved generation equipment efficiency

F2 Lighting redesign and management (street, building, etc.)

F3 Upgrading of transmission lines and/or substation equipment

F4 Improved boiler and equipment maintenance

F5 Better sizing of boilers and/or equipment

F6 Electric motor replacements 
TABLE 1 (Cont.)

\begin{tabular}{|c|c|}
\hline $\begin{array}{c}\text { Code } \\
\text { Activity }\end{array}$ & Description \\
\hline F7 & Areawide resource assessments \\
\hline F8 & Agricultural improvements that conserve energy such as: \\
\hline F8a & Irrigation pump utilization/scheduling \\
\hline F8b & Irrigation pump testing or efficiency improvements \\
\hline F8c & Ditch lining and piping \\
\hline F8d & Laser land-leveling \\
\hline F8e & Pump-back systems \\
\hline F8f & Alternate energy-saving water sources \\
\hline F8g & Field irrigation system improvements \\
\hline F9 & Any other generation or transmission efficiency improvements \\
\hline F10 & Power factor corrections \\
\hline \multicolumn{2}{|c|}{ Category G - Other } \\
\hline G1 & $\begin{array}{l}\text { Other energy conservation activities such as activities initiated under the } \\
\text { U.S. Department of Energy (DOE) Residential Conservation Service (RCS) } \\
\text { Program, Commercial and Apartment Conservation Service (CACS) } \\
\text { Program, or other federal/state/local programs }\end{array}$ \\
\hline G2 & Least-cost strategic planning \\
\hline
\end{tabular}

are those specified by the customers in the program submittals. The goals are to be used in the two-year program verifications submitted to evaluate the progress and effort of the utility in accomplishing its C\&RE goals.

The third important element in the C\&RE-SLC database is an extensive description of the activity. The descriptions usually provide a specific explanation of the activity. All details relevant to C\&RE analysis have been included in these description fields. Some activities such as energy audits require little discussion.

The information contained in the C\&RE-SLC database has been used as the foundation of the C\&RE analysis. Some essential statistics compiled from the database summarize the customer activities. Tables 2 and 3 show the distribution of customer programs since 1981. Table 2 lists the number of C\&RE programs by activity type for each of the plan years. As shown in Table 2, the total number of programs has increased significantly over the period. A more accurate representation of total customer programs is reflected by computing the two-year rolling average, because customers are required to submit updates to their energy plans every two years. The two-year average was calculated and is provided in Table 2 along with program totals. The data generally indicate an increase in the number of programs from year to year, with 1989 being the notable exception. 
TABLE 2 Frequency Distribution of C\&RE Activities by Major Activity Type

\begin{tabular}{|c|c|c|c|c|c|c|c|c|c|c|}
\hline \multirow{2}{*}{$\begin{array}{l}\text { Act. } \\
\text { Type }\end{array}$} & \multicolumn{10}{|c|}{ Activities by Year (Raw Count) } \\
\hline & 1982 & 1983 & 1984 & 1985 & 1986 & 1987 & 1988 & 1989 & 1990 & 1991 \\
\hline A & 2 & 16 & 10 & 18 & 40 & 99 & 121 & 61 & 141 & 132 \\
\hline B & 0 & 0 & 2 & 5 & 2 & 15 & 10 & 4 & 10 & 18 \\
\hline $\mathrm{C}$ & 0 & 1 & 1 & 2 & 4 & 9 & 23 & 6 & 28 & 22 \\
\hline $\mathrm{D}$ & 0 & 0 & 0 & 0 & 4 & 5 & 2 & 0 & 3 & 1 \\
\hline $\mathrm{E}$ & 0 & 0 & 0 & 1 & 3 & 4 & 8 & 1 & 7 & 6 \\
\hline $\mathrm{F}$ & 0 & 0 & 5 & 11 & 25 & 68 & 48 & 36 & 67 & 69 \\
\hline $\mathbf{G}$ & 0 & 0 & 0 & 0 & 0 & 1 & 0 & 0 & 3 & 0 \\
\hline Total & 2 & 17 & 18 & $37^{\circ}$ & 78 & 201 & 212 & 108 & 259 & 248 \\
\hline $\begin{array}{l}2 \text {-yr } \\
\text { average }\end{array}$ & & 10 & 18 & 28 & 58 & 140 & 207 & 160 & 184 & 254 \\
\hline
\end{tabular}

TABLE 3 Percentage Distribution of C\&RE Activities by Major Activity Type

\begin{tabular}{|c|c|c|c|c|c|c|c|c|c|c|}
\hline \multirow{2}{*}{$\begin{array}{l}\text { Act. } \\
\text { Type }\end{array}$} & \multicolumn{10}{|c|}{ Activities by Year (\% of Total) } \\
\hline & 1982 & 1983 & 1984 & 1985 & 1986 & 1987 & 1988 & 1989 & 1990 & 1991 \\
\hline A & 100.0 & 94.1 & 55.6 & 48.6 & 51.3 & 49.3 & 57.1 & 56.5 & 54.4 & 53.2 \\
\hline $\mathrm{B}$ & 0.0 & 0.0 & 11.1 & 13.5 & 2.6 & 7.5 & 4.7 & 3.7 & 3.9 & 7.3 \\
\hline $\mathrm{C}$ & 0.0 & 5.9 & 5.6 & 5.4 & 5.1 & 4.5 & 10.8 & 5.6 & 10.8 & 8.9 \\
\hline $\mathrm{D}$ & 0.0 & 0.0 & 0.0 & 0.0 & 5.1 & 2.5 & 0.9 & 0.0 & 1.2 & 0.4 \\
\hline $\mathrm{E}$ & 0.0 & 0.0 & 0.0 & 2.7 & 3.8 & 2.0 & 3.8 & 0.9 & 2.7 & 2.4 \\
\hline$F$ & 0.0 & 0.0 & 27.8 & 29.7 & 32.1 & 33.8 & 22.6 & 33.3 & 25.9 & 27.8 \\
\hline$G$ & 0.0 & 0.0 & 0.0 & 0.0 & 0.0 & 0.5 & 0.0 & 0.0 & 1.2 & 0.0 \\
\hline Total & 100.0 & 100.0 & 100.0 & 100.0 & 100.0 & 100.0 & 100.0 & 100.0 & 100.0 & 100.0 \\
\hline
\end{tabular}

The frequency distribution of customer programs as shown in Table 2 is converted to percentages in Table 3. More than 50\% of the customer programs fall into category A (energy consumption efficiency programs), which involves the demand side of the market. The next highest category of customer activities, F (production efficiency improvements), relates to the supply side of the electricity market. Activities targeting improvements in production efficiency comprise approximately $30 \%$ of all activities.

The top three ranking customer activities within the energy consumption efficiency improvements (category A) were information dissemination, lighting conversions, and infrared heat detection equipment. For information dissemination (activity type A4), Western's customers indicated that conservation awareness was increased through a variety of communication mechanisms including quarterly publications, bill-stuffers, radio/newspaper 
advertisements, and conservation seminars. The majority of customers indicated a goal of promoting conservation, which is an example of the nonquantitative goals that were found in many planning documents. Similarly, energy-efficient lighting conversions and use of infrared heat detection equipment (activity types A18 and A15) typically had goals that indicated penetration rates rather than energy savings. If the goals in the C\&RE-SLC had been stated as energy savings, the C\&RE analysis for this EIS would have been easier because the study could have modeled the major C\&RE activities in each EIS alternative and compared them to the quantitative goals estimated by the customers.

\subsection{ESTIMATING THE REDUCTIONS FROM CURRENTLY OPERATING C\&RE ACTIVITIES}

The second step of the analysis was to determine the reductions currently being realized by Western's customers from their C\&RE activities. Quantitative program evaluations of the C\&RE activities, however, are not performed by Western. It was, therefore, necessary to estimate the reductions from other information. To acquire such information, analysts solicited information from Western's customers through telephone interviews and drew on estimates published in public sources. In cases where Western's customers could not provide estimates and no published information was found, the judgment of analysts was used. It is recognized that these estimates must be viewed as subject to possible inaccuracy; better estimates must await the institution of a thorough evaluation process by Western.

The objective of the analysis was to estimate the peak load and energy sales reductions of the C\&RE activities on peak demand and energy consumption for the 1990 and 1991 plan years. Two plan years were used because Western's customers are required to develop and submit planning documents every other year, and the choice of two years enabled the analysts to include nearly all Salt Lake City Area customers. Plan year 1992 could not be used because the analytical process began before the end of 1992 and not all customers submitting plans in 1992 would have sent in their documents.

Our telephone interviews could not canvass all of Western's customers for budgetary

reasons. However, the database provided a foundation for the survey. A total of 35 customers were contacted. The information solicited dealt directly with the estimations of the peak demand and annual energy reductions from the currently operating C\&RE activities. Additional information not contained in most C\&RE plans but useful for analytical and assessment purposes was also requested, including average annual load factor, customer composition, customer class contribution to peak load, and summer and winter peak values. Questions specific to each C\&RE activity were also asked, such as "How do you measure the effectiveness of your C\&RE programs?" and "Do you monitor/special-meter various customer classes?"

A general finding from the telephone interview was that thorough program evaluations are needed. Western's customers often lack hard data on the C\&RE activities they have implemented. Of the 35 utilities contacted for additional information, 15 were 
unable to provide details about the energy or peak demand reductions associated with the specific activities currently implemented in their service territories. Some reasons for the lack of quantitative information were offered, such as the following:

- Cost - For several customers, evaluating programs with follow-up surveys or end-use metering would make the cost of the activity prohibitive. These customers believed that their activities are barely cost-effective, even in the absence of evaluation.

- Confounding effects - Isolating the effects of conservation activities, such as information dissemination, is thought to be extremely difficult. In addition to the cost considerations, it is difficult to determine whether appliance purchases were a result of heightened awareness (audits, bill stuffers, seminars, posters, commercials) or would have been undertaken in the absence of C\&RE activities (the free rider effect).

- Growth - Several customers mentioned high growth and/or turnover rate as another obstacle to measuring the effectiveness of conservation activities.

To target the most numerous C\&RE activities represented in the database, telephone interviews concentrated on activities with the highest customer participation rates. Table 4 lists the frequency distribution extracted from the C\&RE-SLC database. The sample of customers included in the telephone interview was taken from the population of customers with these activities. The analyst conducting the interview requested information on all C\&RE activities offered by the surveyed customer, not just the activities listed above.

TABLE 4 Activities with Highest Customer

\section{Participation Rates}

\begin{tabular}{lcl}
$\begin{array}{c}\text { Activity } \\
\text { Type }\end{array}$ & Frequency & \\
\hline A15 & 48 & \multicolumn{1}{c}{ Activity } \\
A18 & 46 & $\begin{array}{l}\text { Infrared heat detection equipment } \\
\text { Energy-efficient lighting conversions }\end{array}$ \\
A2 & 30 & $\begin{array}{l}\text { Energy audits } \\
\text { Information dissemination }\end{array}$ \\
B15 & 59 & Small-scale hydro \\
C1 & 17 & Load management devices \\
F10 & 22 & $\begin{array}{l}\text { Power-factor corrections } \\
\text { Upgrading of transmission lines and/or } \\
\text { F3 }\end{array}$ \\
Fubstation equipment \\
F9 & 47 & $\begin{array}{l}\text { Miscellaneous generation or transmission } \\
\text { efficiency improvements }\end{array}$ \\
\hline
\end{tabular}


Discussions with customers concerning the activities in Category A (A15, A18, A2, and $\mathrm{A4}$ ) indicated that peak load management was not an important consideration. In the estimates of activity A15, peak demand savings were less than $1 \%$. Similarly, the estimates for activity A18 were less than 1\% for both peak demand and annual energy. No estimates could be developed from the telephone interviews for activities A2 and A4.

Almost all of the power system upgrade activities fall into the type $F$ categories, although identification of substation losses was frequently listed as the primary application for infrared heat detection equipment, included as an A15 program. Customers had more information on the effectiveness of system production/operation enhancement programs than most other activities because increases in energy efficiency of transmission and distribution activities can be estimated directly from data collected in the course of doing business. For activity F10, three estimates were developed with reductions in losses of 1, 1.3, and 5\%. For activity F3, eight estimates were given in the customer survey. Five of these estimates were $1.5 \%$ or less; one estimate was $2.5 \%$; and two estimates were $5 \%$. In activity F9, all estimates were $2 \%$ or less.

Estimates for reductions due to small-scale hydro (B15) were greater than $10 \%$ in some cases. The three estimates reported savings of $7.9,0.37$, and $11.3 \%$. Small-scale hydro, however, is not an available option to most customers.

For load management activities (category C), customers estimated that peak demand reductions can be substantial for particular end-user groups. One customer estimated that activity $\mathrm{C} 1$ reduced peak demand by $7 \%$, and another customer estimated peak demand reductions of $5 \%$. These reductions apply to only a very small number of hours during the year, and annual energy savings are negligible. Also, in the C\&RE-SLC, many of the load management activities are listed as being in a pilot stage or implemented only for local government buildings or for a very narrow class of end-users.

To move from the estimates solicited from the telephone interview to estimates generally applicable to the activities represented in the C\&RE-SLC database for the 1990 and 1991 plan years, the estimates were compared and supplemented with estimates from EPRI publications whenever possible (EPRI 1987, 1989, 1990b, 1991a, and 1992).

A total of $510 \mathrm{C} \& \mathrm{RE}$ activities needed estimates. These activities are the observations contained in the C\&RE-SLC database for plan years 1990 and 1991 . Because the estimates from the telephone interviews and the EPRI reports were generally given in percentages, the first task of the analysis was to find either the peak demand or the annual energy sales for each system. This information was usually included in the plan filings of Western's customers and was included in the C\&RE-SLC database. On the basis of the analysts' experience and telephone interviews with 19 customers of Western, a system load factor of $52 \%$ was assumed reasonable. The load factor assumption permitted movement between estimates of peak demand and annual energy sales when one statistic was missing.

To combine the information gathered from the telephone interviews and from the EPRI reports, similar activities are grouped together and reductions are estimated with a 
single set of per customer estimates. For instance, the activities in category $A$ are divided into four subcategories: (1) information dissemination (activities A4-A9, A11, A12, A14, A16, $\mathrm{A17}$, and A20); (2) lighting conversion (A18); (3) infrared heat detection (A15); and (4) building conservation activities and energy audits (A1-A2). Information supplied by the utilities was used along with the EPRI estimates to develop per-end-user estimates that could be related to the size of the customer and applied to the customers not interviewed or unable to provide estimates. Analysts needed to make assumptions about coincidence factors across Western customers as well as the average number of days requiring space heating.

For the activities in the subcategory of information dissemination (A4-A9, A11, A12, A14, A16, A17, and A20), the objective is to reduce energy consumption through increased energy awareness. None of the utilities could provide precise quantitative information regarding $\mathrm{kW}$ or $\mathrm{kWh}$ reductions per customer. There was general agreement that the level of reductions will not be substantial and that many customers will not persist in applying conservation practices unless the conservation message is reinforced. Similarly, the literature search yielded no firm estimates of $\mathrm{kW}$ or $\mathrm{kWh}$ reductions. In the absence of quantitative information, it was assumed that the information dissemination activities taken collectively would be unlikely to reduce energy sales on a continuing basis by more than $0.5 \%(=0.005)$ of the customer's annual sales; that is,

$$
G W h \_R e d=0.005 \times G W h \_s o l d \text {, }
$$

where $G W h \_R e d$ is the energy reductions from the activity and $G W h \_s o l d$ is the energy sales for the individual customer. The average peak load reduction, $M W \_$Red, is given by

$$
M W \_R e d=0.5 \times 1,000 \times G W h \_R e d /(0.52 \times 365 \times 24) .
$$

We assume a coincidence factor of 0.5 and a load factor of 0.52 . The adjustment of 1,000 converts gigawatts to megawatts.

Greater information for lighting conversion activities (A18) was available from some customers. The telephone interviews offered an estimate of the equivalent of approximately 400 efficient commercial lighting conversions occurring in an average activity. It is assumed that commercial lights operate an average of $10 \mathrm{~h} / \mathrm{d}$ for $365 \mathrm{~d} / \mathrm{yr}$, that $50 \mathrm{~W}$ per converted light is saved, and that all savings occur at the time of the peak.

$$
\begin{aligned}
& \text { GWh_Red }=400 \times 10 \times 50 \times 365 / 1,000,000,000 \\
& M W \_R e d=400 \times 50 / 1,000,000
\end{aligned}
$$

The C\&RE-SLC database indicated that the majority of infrared heat detection activities are targeted at residential and commercial customers. The interviewed customers could not quantify expected energy or peak load reductions from the infrared heat detection activity (A15). However, an EPRI publication on residential DSM programs (EPRI 1989, pp. 1-16) suggests that a reasonable estimate of savings is $0.121 \mathrm{~kW}$ per test. This per-test savings for weatherization programs, an average range of 0.04-0.25 kW per installation, was 
used. Total activity energy reduction was estimated by multiplying the number of tests per year by the $\mathrm{kW}$ savings per test. A reasonable number of tests per customer is one test for every $10 \mathrm{GWh}$ of energy sales by the customer. In other words, a customer with sales of $200 \mathrm{GWh}$ in a year would conduct 20 energy efficiency tests with its infrared equipment in a year; that is,

$$
G W h \_R e d=0.1 \times G W h \_s o l d \times 0.121 \times 92 \times 20 / 1,000,000 .
$$

The above equation assumes an average of $92 \mathrm{~d}$ requiring space heating in the year and an average of $20 \mathrm{~h}$ of heating on those days. If only half the customers implementing this activity are winter peaking, the peak-load reduction will be

$$
M W \_R e d=0.5 \times 0.1 \times G W h \_s o l d \times 0.121 / 1,000 .
$$

Building conservation (A1) and energy audit (A2) activities share much of the structure with the infrared heat detection activity. In general, the energy reduction was calculated by multiplying the number of audits by the $\mathrm{kWh}$ savings per audit. Nearly $70 \%$ of the utilities with energy audit specified the number of audits performed annually. Those customers with $<100 \mathrm{GWh}$ of annual sales performed 10 audits; those customers with annual sales of 100-200 GWh performed 50 audits; and those customers with $>200 \mathrm{GWh}$ of annual sales performed 100 audits.

In a further simplification, it was assumed that a customer would conduct an average of one audit for every $3 \mathrm{GWh}$ of energy sales. An average savings of $0.411 \mathrm{~kW}$ was determined from EPRI surveys of residential and commercial energy audit programs. For commercial customers, the average savings per audit is $1 \mathrm{~kW}$ (EPRI 1992, pp. 1-10); however, for residential customers, the average savings per audit is only $0.215 \mathrm{~kW}$ (EPRI 1989, pp. 1-16). Because the information from the C\&RE database indicated that nearly $75 \%$ of the energy audit programs target residential customers, a weighted average of the two savings values was applied.

$$
\begin{aligned}
& \text { GWh_Red }=0.34 \times G W h \_s a l e s \times 0.411 \times 92 \times 20 / 1,000,000 \\
& M W \_R e d=0.5 \times 0.34 \times G W h \_s a l e s \times 0.411 / 1,000
\end{aligned}
$$

Western's customers with activities outside of category A showed quantitative information in their planning more frequently than did customers with just energy conservation activities. For instance, most customers reporting category B activities (renewables) provided estimates of the electricity generated with renewable energy sources. These estimates have been used when present. In the few cases where no quantitative estimates are reported, the overall average of $0.1 \%$ of total GWh sales is imputed to those customers. A load factor of $52 \%$ is applied to convert between energy sales reductions and peak load reductions. Zero savings were assigned to two renewable programs that were research in nature, B11 and B6. 
The planning documents included in the C\&RE-SLC indicated that a majority of customers with category C (load management) activities are in the investigative phase. These customers are analyzing consumption patterns, purchasing metering equipment, and/or conducting surveys. While this is a necessary step, little has been realized in terms of actual reductions in peak demand. Peak load reduction estimates were used when included in the C\&RE-SLC. Zero reductions to peak demand were assumed for customers that have not already installed load management devices. Furthermore, because load management activities impact only a small number of hours in the year, no energy sales reductions were imputed at the GWh level.

There are only four category $\mathrm{D}$ (cogeneration) activities for plan years 1990 and 1991. Reduction estimates were taken directly from the C\&RE database, except for one customer that gave no estimate. In that case, the cogeneration unit was assumed to yield a reduction in energy equal to $1 \%$ of its GWh sales. A load factor of $52 \%$ is applied to convert between energy sales reductions and peak load reductions.

Quantitative information was not available for 13 of the 14 category $\mathrm{E}$ (rate design) activities in the C\&RE-SLC database. The exception was a time-of-use rate design, which claimed to reduce peak demand by 3.5\%. A comparison of estimates provided by EPRI (1990b, pp. 7-8 and 7-9) suggests that the 3.5\% reduction should apply only to the commercial end-users receiving time-of-use rates and not to Western's entire customer base. If it is assumed that commercial end-users represent $40 \%$ of the customers' peak load, that the large customers represent $30 \%$ of the commercial class, and that the coincidence factor for large customers is 0.8 , then the peak load will be reduced by $0.34 \%$. Moreover, because time-of-use rates are designed to shift load, no reduction in energy sales is assumed.

For several category $\mathrm{E}$ activities, special considerations were made. A customer reporting activity E6 (purchase of customer-generated renewable energy) provided quantitative information in the telephone interview. This information was used as our estimate. Activities that are assumed not to reduce peak load or energy sales include cost of service pricing, elimination of declining block rates, sale and purchase of surplus power to displace petroleum fuels, and rate restructuring/adjustments.

Category F (production efficiency) activities are a broad group of supply-side improvement projects. Though such improvement projects can substantially reduce losses in the generating plants, on the transmission grid, and in the distribution system, one must be cautious about imputing energy reductions to actions that would have occurred without the C\&RE activity requirements. In addition, it should be recognized that production efficiency improvements are actions that reduce losses within the system rather than directly offset demand. For these reasons and because little useful quantitative information on energy savings was available in the C\&RE-SLC database or from the telephone interviews, it was assumed that a $0.25 \%$ decrease in energy requirements would result from production efficiency improvements. This overall impact was allocated to the individual utilities according to its share of total GWh sales. Once reductions in energy were calculated, a 52\% load factor was used to impute peak demand reductions. 
Three category G (other) activities appeared in the 1990 and 1991 planning documents. All three were listed as activity G1 (other energy conservation activities). It was assumed that these activities would share the characteristics of energy audits (activity A2).

From these estimates, it was concluded that the total energy sales reduction from the C\&RE activities currently operating is approximately $1.8 \%$. The reduction in peak load is estimated at approximately $3 \%$, assuming that the coincidence factor across Western's customers is 0.45 . These estimates of necessity were made on the basis of very limited information. However, the results conform to the findings in the DSM analysis (Section 4) that (1) Western's customers have few incentives to clip peaks with peak load management programs and (2) the cost of Western's power makes conservation programs uncompetitive.

\subsection{IDENTIFYING C\&RE ACTIVITIES AFFECTED BY THE EIS ALTERNATIVES}

Following the estimation of the reductions associated with the C\&RE activities, analysts identified the activities that could be affected by shifts from the baseline to some EIS alternative marketing plan. It was found that those C\&RE activities likely to be affected were similar to the DSM programs modeled in the DSM analysis (Section 4). The similarity enabled the analysts to unify the modeling effort and reduce the costs associated with the task.

For a variety of reasons, many activities are unlikely to be affected by shifts from one EIS alternative to another. For instance, the activities included in category F (production efficiency) are likely to continue under all EIS alternatives. Supply-side improvement projects that are directed at reducing losses will usually be cost-effective for direct technological reasons rather than because of the indirect impacts of prices or end-user demands. Category $\mathrm{F}$ activities were excluded from further consideration because they are unrelated to the changes in Western's electric power marketing plans.

Two other categories of C\&RE activities that were excluded from consideration as possibly affected activities are category B (renewable energy activities) and category D (cogeneration). Analysts in the Power Systems Task Group studied renewable energy and cogeneration technologies for possible inclusion among the supply-side options in utility expansion plans. They found that renewable energy programs and cogeneration are not currently cost-competitive under any of the EIS alternatives. Though there are some renewable energy and cogeneration projects within Western's Salt Lake City Area, these activities arise from influences other that cost-effectiveness. It is assumed that the noncost-effectiveness rationale for the renewable energy and cogeneration projects will continue under any marketing plan, that is, under any EIS alternative.

We found that it was necessary to exclude all category $\mathrm{E}$ (rate design) activities for reasons of lack of relevant cost information. This difficulty is not believed to create a substantial bias because rate design activities accounted for only 14 of the 510 activities included in the 1990 and 1991 plans. It was also noted that the estimated impacts of the rate design activities are small. 
The three remaining activity categories were category $A$ (energy consumption efficiency improvements), category C (load management techniques), and category G (other activities). These categories include the types of DSM programs discussed in Section 4. It was reasoned that if the appliance, motor, or lighting programs of Section 4 showed little or no change between alternatives, then neither would the category $A$ or category $\mathrm{G}$ activities. Similarly, if the residential air conditioning direct load control program displayed no change from one EIS alternative to another in our DSM analysis, then the C\&RE activities directed at peak load management would also be equally cost-effective in all EIS alternatives.

\subsection{MODELING POTENTIALLY AFFECTED C\&RE ACTIVITIES}

The final step in the C\&RE analysis involved modeling the costs and reductions of the selected activities under the EIS alternatives as well as the baseline. At this point, the C\&RE analysis was joined with the DSM analysis because the activities remaining after the third step were similar to the DSM programs being modeled as part of the capacity expansion analysis. The 18 DSM programs that were modeled with the EPRI software DSManager (EPRI 1991c) show a broad range of energy conservation programs such as those listed in categories A and G. Also included in the DSM programs modeled is a peak load management program similar to those found in Category C.

A full description of the modeling method is given in Section 4. By modeling with EPRI's DSManager, the costs and benefits of the C\&RE activities are evaluated. DSManager uses program cost information, estimates of program participation, and marginal system energy cost estimates. The marginal system cost estimates for the Baseline Alternative and Alternatives 5 and 6 were generated from ANL's Production and Capacity Expansion (PACE) model by the Power Systems Task Group. Appropriate program costs and participation were determined through consultation with experienced DSM analysts and compared to ranges of estimates used in similar studies. The cost-benefit ratios generated by DSManager for each program were compared between the Baseline and Alternatives 5 and 6.

The C\&RE analysis found that the alternative marketing plans display no significant differential impacts on currently operating C\&RE activities. Because of the narrow variation in the hourly marginal system costs in each alternative after accounting for power purchased by customers from Western, only 6 of the 18 modeled DSM programs were cost-effective in some alternative, and only 5 were cost-effective in all alternatives. This narrow variation from hour to hour does not permit cost-effective implementation of peak load management activities. Furthermore, the low cost of power supplied by Western and the excess baseload capacity of many customers result in few cost-effective energy conservation programs and no significant differences between alternatives in the cost-effectiveness of energy conservation programs. 


\section{FORECASTS OF THE COSTS AND REDUCTIONS FROM COST-EFFECTIVE DEMAND-SIDE MANAGEMENT PROGRAMS}

\subsection{INTRODUCTION}

In developing forecasts of the supply requirements placed upon an electric utility, one must account for the expected energy and demand reductions associated with programs sponsored by the utility to reduce the demand for electricity. These DSM programs are currently being implemented in many parts of the United States to conserve resources and reduce environmental damage. DSM programs can include incentives to curtail use during peak load periods and rebates offered by a utility so that end-users will purchase energyefficient appliances. Many of the currently operating C\&RE activities of Western's customers are DSM programs.

This analysis has separated the forecast of energy and peak load reductions associated with DSM programs from Western's currently operating C\&RE activities. This separation is related to a change in motivation on the part of Western's customers. In the past, Western's customers were required to choose from three to five activities for implementation to meet the obligations of the G\&AC as amended in 1985. Though the costeffectiveness of an activity was probably a major factor in its choice, it was not the only motivation. In the future, Western's customers will be required to develop IRPs under the Energy Policy and Management Program. The essential characteristic of IRP is competition among DSM and resource options to provide the least-cost method of meeting end-use needs. Cost-effectiveness is the essential element in IRP, and the method used in this analysis focuses exclusively on cost-effectiveness.

The goals of the DSM analysis are to develop reasonable estimates of the energy $(\mathrm{kWh})$ and peak load (MW) reductions from cost-effective DSM programs. The utility DSM program costs, the DSM participant costs, and the participation rates for each cost-effective DSM program are also estimated. Furthermore, estimates for several of the EIS alternatives have been developed.

This section describes in detail the method used to develop the cost-effective DSM program results. The important assumptions in the analysis are also identified, and the findings are reported. The method involved a five-step approach. ${ }^{1}$ First, a set of possible DSM options was developed. These were DSM programs that have been implemented at U.S. utilities and have a likelihood of developing cost information. Second, the number of DSM options was reduced to a computationally manageable number without eliminating options that would prove cost-effective. Third, the remaining DSM programs were investigated to develop all the necessary cost information and the per-customer energy and peak reductions.

1 The method used to develop cost-effective DSM programs is patterned after the method used by the Potomac Electric Power Company (PEPCO) in its 1990 and 1992 integrated resource plans. A detailed description of the method is given by PEPCO (1990). The PEPCO method has also been described and analyzed by Hill et al. (1991). 
Fourth, the hourly reductions and the cost-effectiveness of the potential DSM program were computed by using the forecasted marginal costs for the Colorado Spring Municipal Electric Utility. These calculations were made with the DSManager computer program. Last, the estimated DSM program reductions were integrated into the hourly demand forecasts of Western's major systems being modeled with ANL's PACE model by the Power Systems Task Group.

\subsection{DSM OPTIONS AND INITIAL SCREENING}

The initial step of the method was to assemble a large set of DSM options for possible inclusion in the expansion plans. To assemble that set, analysts consulted EPRI reports (EPRI 1987, 1989, 1991a, and 1992) and the Survey Information System (SURIS) database that was compiled by EPRI (1991b). Additional DSM options were drawn from material submitted as testimony from the Executive Director of the American Public Power Association to the U.S. House of Representatives, Subcommittee on Water, Power and Offshore Energy Resources (Hobart 1992). In this initial step, no attempt was made to eliminate DSM programs or measures that might later be rejected as inappropriate for the local region.

After assembling the initial set of more than 100 DSM options, analysts performed an initial screening to reduce the DSM options to a number that is both computationally manageable and inclusive of cost-effective programs. The initial screening rejected DSM options that, by the consensus of a group of analysts, did not meet the following criteria: (1) applicability in the Western region, (2) market maturity, and (3) acceptable level of reductions. These criteria were used to screen out possible DSM programs that would almost certainly not meet local needs in a cost-effective manner. The resulting set of DSM programs included 18 programs - 10 residential, 5 commercial-industrial, and 3 agricultural.

\subsection{DSM PROGRAM COST AND PARTICIPATION ESTIMATES}

The 18 DSM programs remaining after the initial screening were then intensively researched to develop reasonable cost estimates for the utility and for the participating endusers. Participation rates were also estimated for the end-user and free-rider rates. Because much of the needed information is not publicly available in printed form, the analysts and consultants had to draw on their own judgment and past experience along with the experience of colleagues in the utility industry. The estimates and assumptions for the 18 DSM programs are given in the program summary sheets in the Appendix.

\subsection{DSMANAGER MODELING}

Given the utility and participant cost information and the participation levels, the analysis proceeded by estimating the cost-effectiveness of 18 DSM programs. Because costeffectiveness depends on the cost of the energy that does not need to be produced as a result 
of the DSM program, a crucial piece of information is the hourly marginal system energy cost. The hourly marginal system energy cost is the cost avoided by offsetting $1 \mathrm{MW}$ of power with an equal amount of reduction in demand from a DSM program. With Colorado Springs Municipal Utility as the prototypical system, the forecasted hourly marginal system energy cost was used as the avoided cost. The forecast was developed by the Power Systems Task Group using the PACE model.

By using a prototypical system, the analysis was able to avoid the leveling effect that an aggregation of the entire Salt Lake City Area service territories would have had on the load shape and marginal costs used for DSM screening purposes. For instance, by combining summer- and winter-peaking utilities into a single entity for analytical purposes, the load shape would inevitably have been flattened. This, in turn, would produce questionable DSM results because the variation in the load shape and corresponding marginal system energy costs drive the economics of many DSM programs. Additionally, by using some type of aggregated system to represent Western, the analysis would have been based upon an entity that does not really exist. The costs of energy would likewise have been fictional, and therefore any conclusions regarding the relative benefits of DSM programs would be purely hypothetical. For these reasons, the use of a real utility for the analysis was preferable, even though this utility may not perfectly represent every other utility in the Salt Lake City region.

Despite the use of an actual utility, one surprising finding in the analysis was the flatness of the hourly marginal system energy costs. Because the marginal cost data ultimately determine the economic viability of DSM programs, the discovery of the flat hourly marginal costs raised concerns. Further investigation, however, showed that the hourly marginal systems costs forecasted by PACE for other major Western systems displayed the same flatness. After extensive discussions, it was concluded that the flatness of the hourly marginal system energy costs is due to Western's customers use of the low-priced hydro resource provided by Western to meet peaking need whenever possible. This practice would lower the marginal energy cost during peaking hours and would reduce the need for expensive peaking units owned by the customers. Western's Salt Lake City Area Office staff found this explanation reasonable, though it must remain a question for future research. Figures 1 and 2 were developed by using the hourly marginal system energy costs for the Colorado Springs Municipal Utility. The figures show the marginal costs for the seasonal peak months of January and June. Other months are similar.

The cost-effectiveness of the 18 DSM programs was developed through the use of the computer program DSManager developed by Electric Power Software for EPRI (EPRI 1991c). DSManager uses program cost information, estimates of program participation, and marginal system cost estimates to compute the costs and benefits of proposed DSM programs. DSManager is a highly data-intensive computer program. In addition to the program information and hourly marginal system energy costs, the additional information that follows was used to estimate the cost-effectiveness.

- Planning horizon - A 20-yr planning horizon was used (1993-2012 inclusive). 


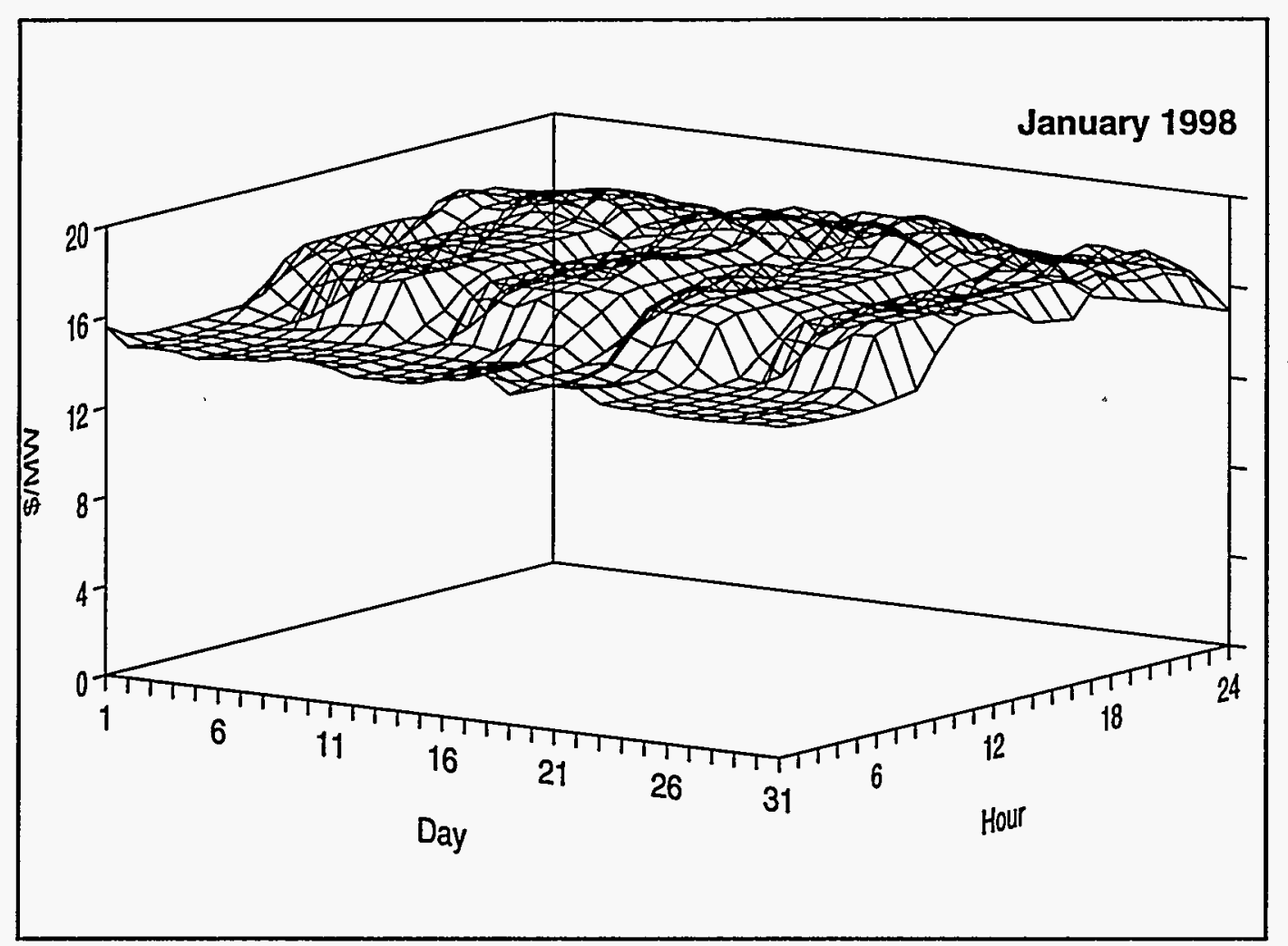

FIGURE 1 Marginal Energy Costs as Forecast by PACE for January 1998

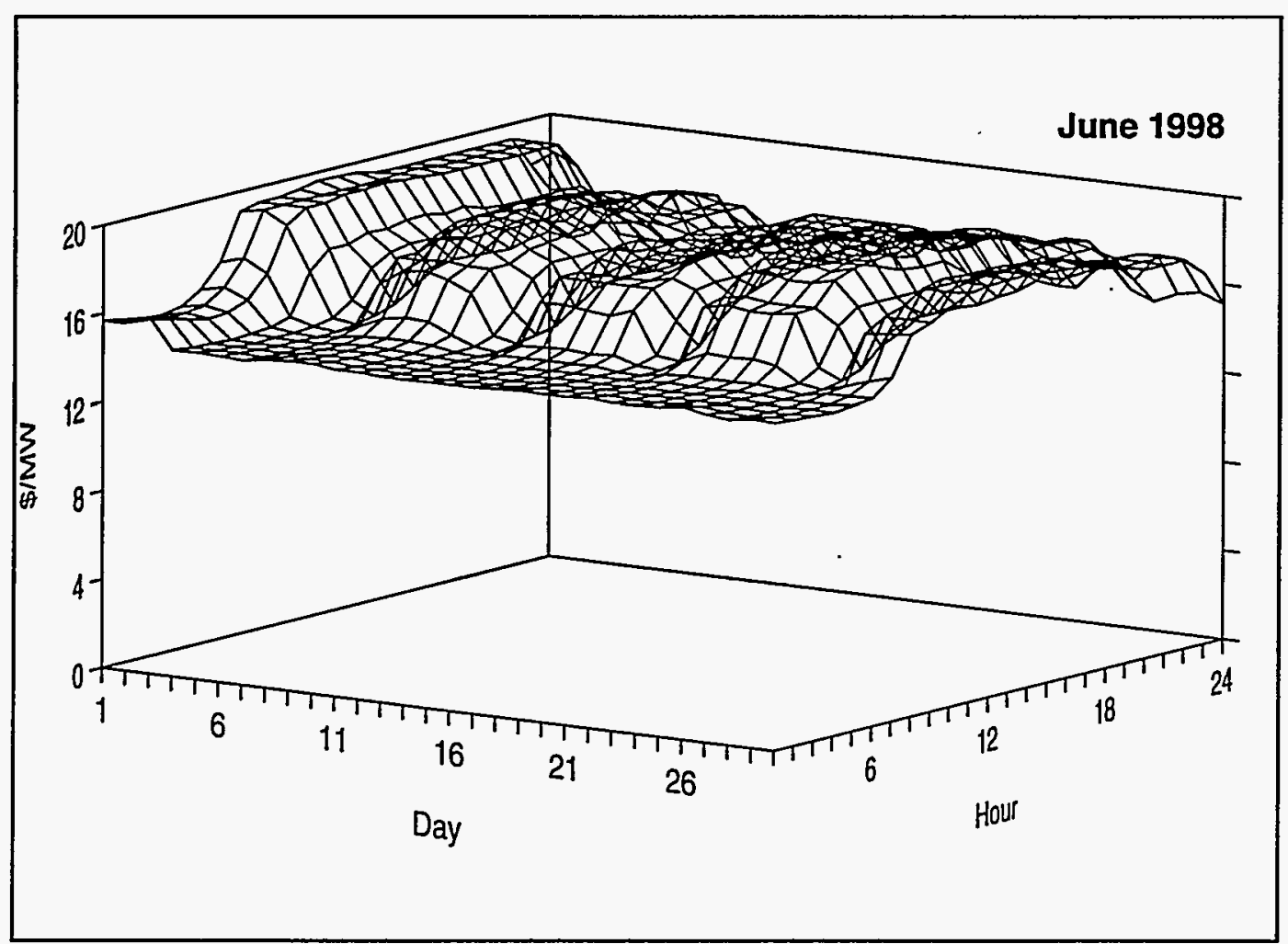

FIGURE 2 Marginal Energy Costs as Forecast by PACE for June 1998 
- Escalation rate - An annual escalation rate of 3.9\% was used for all costs associated with DSM programs. This figure was consistent with the Nominal Escalation Rate for the Glen Canyon Study. This percentage represents the inflationary rise in the costs used in the analysis.

- Avoided capacity costs - These costs are highly utility-specific. They are determined by a number of factors, including load growth, capital costs, and timing of the need for the next generation resource. For this reason, it was decided that a generic, average avoided capacity cost was appropriate for this analysis. The generation avoided cost was assumed to be $\$ 100 / \mathrm{kW}$. The generation avoided cost represents an estimate of a mix of peak load and baseload capacity additions. This aggregate capacity cost was used instead of a pure peaking capacity avoided cost to avoid discrimination against conservation-oriented DSM programs that, in fact, may tend to delay the need for baseload capacity. The transmission and distribution avoided costs are extremely difficult to estimate as they tend to be highly site- and utility-specific; to avoid skewing the results of the analysis, they were assumed to be zero.

- Hourly demand levels - Hourly demand before adjustment for DSM program reductions was developed from the Demand Analysis Task Group with the hourly load profiles developed from the Power Systems Task Group. Minor modifications were made, such as the addition of leap year days in appropriate years.

- Rate schedules - Actual rate schedules from the Colorado Springs Municipal Utility were used for all DSManager analysis.

- Distribution losses - Such losses were assumed to be $6 \%$ for all days in all seasons.

- Discount rates - The following nominal discourit rates were used:

$\begin{array}{ll}\text { Utility } & 10 \% \\ \text { Participant } & 25.99 \% \\ \text { Total resource } & 10 \% \\ \text { Societal } & 25.99 \%\end{array}$

The utility and total resource discount rates reflect an average cost of . capital, whereas the participant and societal rates reflect the typically higher discount rates found among individuals in general. The $25.99 \%$ rate is simply the rate that reflects a payback period of $3 \mathrm{yr}$.

- Externalities - Such were assumed to have no net economic effects.

- Sales tax rate - This rate was assumed to be $5 \%$. 
- Income tax rate - Composite rate (combined state and Federal) of 37.3\%; this includes a state rate of approximately $5 \%$ and a Federal rate of approximately $34 \%$. These tax rates are used only for the utility, commercial, and industrial costs and benefits calculations.

The process of estimating the cost-effectiveness of the 18 DSM programs was implemented three times - for the No Action Alternative (NA, the baseline) and two other alternatives. The No Action Alternative was modeled first. In addition, the DSManager computations were made by using the marginal system energy costs for Alternatives 5 and 6 . Alternative 5 assumes low capacity commitments by Western and a high load factor. Alternative 6 assumes a moderate capacity commitment and a moderate load factor. Alternative 3 was not modeled separately because its marginal system energy cost was not significantly different from the baseline. The DSManager results appear in Table 5. (Table 6 provides definitions for the programs listed on Table 5.) For the sake of completeness, Table 5 presents the results of all five major DSM test ratios; however, the decision to include or exclude a DSM program from the expansion path was based exclusively on the Total Resources Cost Test. This test was the most comprehensive available measure of the overall benefits and costs for the utility and its service territory. The Societal Test would be a more comprehensive measure of well-being but could not be implemented because environmental impacts were not available when the DSM analysis was conducted.

Table 5 shows that 6 of the 18 DSM programs consistently displayed costeffectiveness in all modeled alternatives as determined by the Total Resources Cost Test. The threshold criterion for the inclusion of DSM programs in expansion plans was a Total Resources Cost Test benefit/cost ratio of at least 1.10. This criterion was chosen to recognize the highly uncertain nature of the costs, participation levels, and hourly demand impacts of most DSM programs. In other words, it was considered appropriate to guard against overly optimistic assumptions by raising the threshold slightly above the 1.00 level.

\subsection{DSM REDUCTIONS}

The energy and peak demand reductions from the cost-effective DSM programs for the Colorado Springs Municipal Utility are shown in Table 7. These reductions are derived by summing across the cost-effective DSM programs for each hour of the forecast period. The peak load reduction is the DSM reduction for the hour of maximum load during the year. The energy reduction is the sum of the hourly reductions over the entire year.

The cost-effective programs can be described as energy conserving rather than peak shaving or load shifting. The reason for this result is closely associated with the flatness of the marginal system energy costs. In all alternatives studied, the hourly marginal system costs after accounting for power purchased from Western do not vary enough to provide an economic basis for peak load management programs such as direct load control of residential air conditioners. 
TABLE 5 DSManager Results for Prototypical Utility: Ratios of Present Values for Benefits and Costs

\begin{tabular}{|c|c|c|c|c|c|c|c|c|c|c|c|c|c|c|c|}
\hline \multirow{2}{*}{$\begin{array}{c}\text { DSM } \\
\text { Program }^{a}\end{array}$} & \multicolumn{3}{|c|}{ Participant Test } & \multicolumn{3}{|c|}{ Utility Test } & \multicolumn{3}{|c|}{ Ratepayer Impact } & \multicolumn{3}{|c|}{ Total Resource } & \multicolumn{3}{|c|}{ Societal Test } \\
\hline & NA & Alt 5 & Alt 6 & NA & Alt 5 & Alt 6 & NA & Alt 5 & Alt 6 & NA & Alt 5 & Alt 6 & $\mathrm{NA}$ & Alt 5 & Alt 6 \\
\hline MOTOR5 & 0.98 & 0.98 & 0.98 & 1.13 & 1.13 & 1.12 & 0.85 & 0.84 & 0.84 & 1.00 & 1.00 & 0.99 & 0.63 & 0.62 & 0.62 \\
\hline MOTOR50 & 1.02 & 1.02 & 1.02 & 4.10 & 4.08 & 4.05 & 1.84 & 1.83 & 1.82 & 2.76 & 2.77 & 2.75 & 1.63 & 1.62 & 1.61 \\
\hline COM_LIT1 & 0.74 & 0.74 & 0.74 & 0.52 & 0.52 & 0.51 & 0.38 & 0.38 & 0.38 & 0.37 & 0.37 & 0.37 & 0.36 & 0.36 & 0.36 \\
\hline COM_LIT2 & 0.61 & 0.61 & 0.61 & 0.25 & 0.25 & 0.24 & 0.21 & 0.21 & 0.21 & 0.18 & 0.18 & 0.16 & 0.17 & 0.17 & 0.17 \\
\hline COM_LIT3 & 1.10 & 1.05 & 1.05 & 2.17 & 1.67 & 1.65 & 0.90 & 0.79 & 0.78 & 1.48 & 1.14 & 1.13 & 0.97 & 0.85 & 0.84 \\
\hline RES_AC & 0.89 & 0.89 & 0.89 & 0.28 & 0.29 & 0.29 & 0.17 & 0.17 & 0.17 & 0.21 & 0.21 & 0.21 & 0.14 & 0.14 & 0.14 \\
\hline RES_CD & 0.61 & 0.61 & 0.61 & 0.36 & 0.36 & 0.36 & 0.31 & 0.31 & 0.31 & 0.28 & 0.28 & 0.28 & 0.19 & 0.19 & 0.19 \\
\hline RES_HP1 & 0.52 & 0.52 & 0.52 & 0.43 & 0.43 & 0.42 & 0.41 & 0.41 & 0.41 & 0.30 & 0.30 & 0.30 & 0.28 & 0.28 & 0.28 \\
\hline RES_HP2 & 0.48 & 0.48 & 0.48 & 0.95 & 0.94 & 0.93 & 1.00 & 1.00 & 0.99 & 0.68 & 0.67 & 0.67 & 0.50 & 0.50 & 0.50 \\
\hline RES_LIT1 & 0.77 & 0.77 & 0.77 & 1.68 & 1.67 & 1.66 & 1.02 & 1.02 & 1.01 & 1.66 & 1.66 & 1.65 & 0.85 & 0.85 & 0.84 \\
\hline RES_REF & 1.82 & 1.82 & 1.82 & 1.32 & 1.32 & 1.31 & 0.74 & 0.74 & 0.73 & 1.81 & 1.61 & 1.59 & 1.14 & 1.13 & 1.13 \\
\hline RES_WRAP & 1.41 & 1.41 & 1.41 & 4.54 & 4.53 & 4.50 & 1.52 & 1.51 & 1.50 & 3.18 & 3.17 & 3.15 & 2.21 & 2.20 & 2.19 \\
\hline RES_CW & 0.73 & 0.73 & 0.73 & 0.62 & 0.62 & 0.62 & 0.48 & 0.48 & 0.48 & 0.64 & 0.64 & 0.63 & 0.42 & 0.42 & 0.42 \\
\hline R_DLC_AC & $\mathrm{N} / \mathrm{A}$ & 0.04 & 0.04 & N/A & 0.00 & 0.00 & N/A & 0.00 & 0.00 & N/A & 0.00 & 0.00 & N/A & 0.00 & 0.00 \\
\hline WEATHER & 0.55 & 0.55 & 0.55 & 0.13 & 0.13 & 0.13 & 0.12 & 0.12 & 0.12 & 0.11 & 0.11 & 0.11 & 0.06 & 0.06 & 0.06 \\
\hline IRRIG_1 & 1.84 & 1.84 & 1.84 & 0.88 & 0.87 & 0.88 & 0.41 & 0.41 & 0.41 & 0.96 & 0.96 & 0.97 & 1.00 & 0.99 & 0.99 \\
\hline DAIRY-RF & 0.55 & 0.55 & 0.55 & 0.69 & 0.69 & 0.68 & 0.57 & 0.56 & 0.56 & 0.34 & 0.34 & 0.34 & 0.17 & 0.17 & 0.17 \\
\hline VENT_SYS & 0.51 & 0.51 & 0.51 & 3.50 & 3.49 & 3.47 & 3.31 & 3.29 & 3.27 & 1.75 & 1.74 & 1.73 & 0.85 & 0.85 & 0.84 \\
\hline
\end{tabular}

a Descriptions of these programs are given in Table 6. 
TABLE 6 Description of DSM Programs

\begin{tabular}{ll}
\hline \multicolumn{1}{c}{ Abbreviation } & \multicolumn{1}{c}{ Description } \\
\hline MOTOR5 & Commercial/industrial high-efficiency motors $-5 \mathrm{hp}$ \\
MOTOR50 & Commercial/industrial high-efficiency motors - 50 hp \\
COM_LIT1 & Commercial lighting - high-efficiency fluorescents \\
COM_LIT2 & Commercial lighting - electronic ballast \\
COM_LIT3 & Commercial lighting - lamp removal and reflector \\
RES_AC & Residential high-efficiency air conditioning \\
RES_CD & Residential high-efficiency clothes dryer \\
RES_HP1 & Residential heat pump - ground-source \\
RES_HP2 & Residential heat pump - air-source \\
RES_LIT1 & Residential efficient lighting \\
RES_REF & Residential high-efficiency refrigerator \\
RES_WRAP & Residential water heater insulation \\
RES_CW & Residential high-efficiency clothes washer \\
R_DLC_AC & Residential direct-load-control air conditioning \\
WEATHER & Residential weatherization \\
IRRIG1 & Agricultural irrigation \\
DAIRY_RF & Dairy refrigeration - waste heat recovery \\
VENT_SYS & Earth-tube heat exchange ventilation system \\
\hline & \\
&
\end{tabular}


TABLE 7 Forecasted DSM Reductions - Colorado Springs Municipal Utility

\begin{tabular}{|c|c|c|c|c|c|c|}
\hline \multirow[b]{2}{*}{ Year } & \multicolumn{3}{|c|}{$\begin{array}{l}\text { Energy Reductions (MWh) } \\
\text { from DSM, by Alternative }\end{array}$} & \multicolumn{3}{|c|}{$\begin{array}{c}\text { Peak Reductions } \\
\text { (MW) from DSM, } \\
\text { by Alternative }\end{array}$} \\
\hline & NA & Alt 5 & Alt 6 & NA & Alt 5 & Alt 6 \\
\hline 1993 & 5,626 & 5,357 & 5,357 & 0.92 & 0.88 & 0.88 \\
\hline 1994 & 12,174 & 11,367 & 11,361 & 1.96 & 1.84 & 1.84 \\
\hline 1995 & 21,687 & 20,563 & 20,544 & 3.02 & 2.94 & 2.93 \\
\hline 1996 & 30,705 & 29,136 & 29,100 & 4.82 & 4.58 & 4.58 \\
\hline 1997 & 33,366 & 31,443 & 31,371 & 5.20 & 4.91 & 4.90 \\
\hline 1998 & 35,909 & 33,517 & 33,445 & 5.55 & 5.19 & 5.18 \\
\hline 1999 & 38,526 & 35,652 & 35,578 & 5.95 & 5.52 & 5.51 \\
\hline 2000 & 41,212 & 37,838 & 37,765 & 5.33 & 5.08 & 5.07 \\
\hline 2001 & 44,053 & 40,036 & 39,998 & 5.66 & 5.36 & 5.35 \\
\hline 2002 & 47,176 & 42,612 & 42,581 & 7.18 & 6.50 & 6.49 \\
\hline 2003 & 50,300 & 45,154 & 45,130 & 7.63 & 6.87 & 6.86 \\
\hline 2004 & 53,702 & 47,946 & 47,927 & 8.13 & 7.27 & 7.27 \\
\hline 2005 & 57,235 & 51,093 & 51,008 & 8.64 & 7.72 & 7.71 \\
\hline 2006 & 60,985 & 54,206 & 54,120 & 7.63 & 7.14 & 7.13 \\
\hline 2007 & 64,853 & 57,418 & 57,328 & 8.07 & 7.54 & 7.52 \\
\hline 2008 & 68,941 & 60,808 & 60,717 & 10.32 & 9.11 & 9.09 \\
\hline 2009 & 73,327 & 64,130 & 64,120 & 10.95 & 9.58 & 9.57 \\
\hline 2010 & 77,861 & 67,861 & 67,858 & 11.60 & 10.11 & 10.11 \\
\hline 2011 & 82,525 & 71,686 & 71,692 & 12.27 & 10.65 & 10.65 \\
\hline 2012 & 87,500 & 75,779 & 75,742 & 10.75 & 9.88 & 9.88 \\
\hline
\end{tabular}

In addition to the flatness of the hourly marginal cost, the level of marginal system energy cost is relatively low due to the low cost of conventional sources of supply such as hydro power. The relatively low marginal system costs result in small total reductions from DSM programs and little difference in reductions between alternatives. The low overall reductions from new cost-effective DSM programs for the Colorado Springs Municipal Utility can be seen in the fact that in all years of the expansion period (1993-2012), DSM reductions reached a maximum of $12.27 \mathrm{MW}$ of peak load reduction and $87.5 \mathrm{GWh}$ of energy savings. This is approximately a $1.4 \%$ reduction in peak load demand and a $1.6 \%$ reduction in energy sales. Also, because only one DSM program was in the No Action Alternative and not in the other alternatives, the differences between alternatives due to DSM was small approximately $0.2 \%$ of energy sales in the final year of the expansion period.

The modeling results for the Colorado Springs Municipal Utility were generalized to the other Western systems by proportionally increasing or decreasing the individual hourly 
program reductions. The factor of proportionality was created by the ratio of forecasted 1993 peak demand for each system to the forecasted 1993 peak demand for the Colorado Springs Municipal Utility. See Morey and Ungson (1993) for a presentation of the load forecasts for this EIS. ${ }^{2}$

2 The long-term demand forecast for Tri-State as it appears in Morey and Ungson (1993, p. 67) was not used. The long-term forecast showed a steep decline in all years, ranging from $-5.84 \%$ to $-1.75 \%$ for different years. The average yearly decline was more than $2 \%$. Because there was no separate evidence (such as expected decline in population, expected loss of commercial customer bases, or expected reduction in service territory coverage) to suggest such a decline and because this forecast was at such variance with the forecasts of other systems, the decline was taken to be a statistical artifact. As a substitute forecast, the growth rate for the last year of the short-term forecast (1.96\%) was extended to cover all years of the long-term period (1996-2015). The growth rate of $1.96 \%$ per year is well within reasonable bounds as indicated by similar national forecasts and conforms to the forecasts of other systems in this study. 


\section{CONCLUSIONS AND DISCUSSION}

The primary result from the analysis presented in this report is that no significant impacts on either Western's C\&RE activities or the cost-effective DSM programs are associated with the Electric Power Marketing EIS alternatives. In part, this is due to the estimation that the energy savings and peak load reductions from the C\&RE activities and the cost-effective DSM are relatively small. The analysis also found that the simulations of different alternatives showed almost no differences.

The most likely reason why C\&RE activities offer small reductions and relatively few DSM programs cross the economic threshold is that the marginal system energy costs in all three scenarios are too low and too flat over time for the conservation measures to become competitive with the low-cost power available to Western's customers. In particular, the flat marginal energy costs make it extremely difficult to operate peak shaving or load shifting programs, such as the residential air conditioning DLC program. There is simply not enough of a differential between the peak and the remaining hours of the day for the DLC program to make an impact. Because a utility typically cannot control for a full day at a time, the program offers no economic advantages. Operation of a DLC program under such conditions would simply move - and possibly raise - the peak.

A primary cause of such flat marginal energy curves could be the use of hydro energy for meeting demand at peak periods. Because hydro power tends to have relatively low marginal energy costs, these could flatten out during the hours that otherwise would show a peak both in the load profile and the hourly marginal costs. If this is the case at the Colorado Springs Municipal Utility and if hydro energy is available to a broad range of Western's customers without time-of-use restrictions, the conclusions drawn here concerning the economic disadvantages of DSM programs can be generalized to the rest of the Western system.

In addition, the flat marginal system energy cost curves indicate that the lowest-cost units available to Western's customers are the ones against which DSM must compete. Whether these units are fossil plants or hydro, the economic hurdle for the DSM programs is quite high. In most utilities located in major cities, conservation and DSM programs compete against high-priced peaking units.

One should also note that, from a geographical standpoint, the population and customer make-up of the service territories covered by Western mitigate against DSM for several reasons. First, DSM program implementation is made more difficult and expensive because population density is probably the lowest in the country. In the most successful DSM programs, the utilities have benefited from a compact service territory that allows easy and quick access to customers for servicing and education. Second, the industrial component of the customer base is smaller than for many East and West Coast utilities. This limits the opportunity of some of the most cost-effective DSM programs. And third, the overall costs of DSM programs are probably increased because of the wide variety of climates and altitudes of the service territories involved. DSM programs that make sense for one group of end-users 
would be ineffective for others. 'Given the already mentioned dispersion of the population, the variety of climates and altitudes limits the agglomeration economies possible for DSM programs.

Explaining the existence of flat marginal system energy costs is a matter for further study. Two other areas for further study include the following:

- Western should conduct a thorough evaluation of the C\&RE activities of its customers. Though the estimates in this study may provide a good base, there is no substitute for a carefully developed evaluation program to validate the energy savings that are predicted.

- Western should study assistance for its customers to develop DSM programs that reduce fixed utility costs wherever possible. By being a regional body, Western can facilitate access to the agglomeration economies, such as education, joint buying projects, and standardization of equipment. Though Western has provided this facilitation to some extent in the past, further examination of Western's activities as a regional coordinator of DSM could lead to better DSM programs and less dependence on conventional sources of supply. 


\section{REFERENCES}

Bernard, M.J., et al., 1990, "Electric Utilities: Potential to Reduce Emissions through Demand-Side Management," in South, D.W., et al., Technologies and Other Measures for Controlling Emissions: Performance, Costs and Applicability, NAPAP Report SOS/T-25, in Vol. IV of Acidic Deposition: State of Science and Technology, National Acid Precipitation Assessment Program, Washington, D.C.

Cavallo, J.D., et al., 1992, C\&RE-SLC: Database for Conservation and Renewable Energy Activities, ANL/EAIS/TM-76, Argonne National Laboratory, Argonne, ח1., Aug.

Chema, T.V., 1990, "In Support of Demand-Side Management," Public Utilities Fortnightly, Jan. 18, pp. 11-16.

EPRI, 1987, A Compendium of Utility-Sponsored Energy Efficiency Rebate Programs, EM-5579, Electric Power Research Institute, Palo Alto, Calif., Dec.

EPRI, 1989, 1988 Survey of Residential-Sector Demand-Side Management Programs, CU-6546, Electric Power Research Institute, Palo Alto, Calif., Oct.

EPRI, 1990a, End-Use Energy Efficiency, CU.3032.12.90, Electric Power Research Institute, Palo Alto, Calif.

EPRI, 1990b, Rate Design: Traditional and Innovative Approaches, CU-6886, Electric Power Research Institute, Palo Alto, Calif., June.

EPRI, 1991a, 1990 Survey of Industrial-Sector Demand-Side Management Programs, CU-7089, Electric Power Research Institute, Palo Alto, Calif., Jan.

EPRI, 1991b, SURIS: DSM Survey Information System, Version 3.1, Users Manual, Electric Power Research Institute, Palo Alto, Calif., Dec.

EPRI, 1991c, EPRI DSManager User's Guide, Version 1.5.5, Electric Power Research Institute, Palo Alto, Calif., Nov.

EPRI, 1992, 1991 Survey of Commercial-Sector Demand-Side Management Programs, TR-100329, Electric Power Research Institute, Palo Alto, Calif., Jan.

GAO, 1991, Electricity Supply: Utility Demand-Side Management Programs Can Reduce Electricity Use, GAO/RCED-92-13, U.S. General Accounting Office, Washington, D.C., Oct.

Hill, L.J., et al., 1991, Integrating Demand-Side Management Programs into the Resource Plans of U.S. Electric Utilities, ORNL/CON-311, Oak Ridge National Laboratory, Oak Ridge, Tenn., Jan. 
Hobart, L., 1992, Testimony on H.R. 4126, presented to the Subcommittee on Water, Power and Offshore Energy Resources of the House Committee of Interior and Insular Affairs, by American Public Power Association, Mar. 12.

Lamarre, L., 1991, "Shaping DSM as a Resource," EPRI Journal 16(7), Oct./Nov.

Morey, M.J., and D. Ungson, 1993, Statistical Analysis of the Demand for Electricity and Forecasts of Demand and Load Growth by Major Rate Class and System for Customers of the Western Area Power Administration, prepared by Center for Regulatory Studies, Mlinois State University, Bloomington, for Argonne National Laboratory, Argonne, Ml., Apr. 22.

PEPCO, 1990, 1990 Integrated Least-Cost Resource Plan: 1990 Energy Plan, Potomac Electric Power Company, Washington, D.C. (available through the District of Columbia Public Service Commission).

Western (Western Area Power Administration), 1991, "Intent to Prepare an Environmental Impact Statement on the Proposal to Establish an Energy Planning and Management Program," Federal Register 56(19):995-996, May 1. 
APPENDIX:

PROGRAM SUMMARY SHEETS FOR THE DEMAND-SIDE MANAGEMENT PROGRAMS 


\section{APPENDIX:}

\section{PROGRAM SUMMARY SHEETS FOR THE DEMAND-SIDE MANAGEMENT PROGRAMS}

\section{A.1 COMMERCIAL/INDUSTRIAL HIGH-EFFICIENCY MOTORS -5 HP}

Description

Rate Class

Technology Life

Energy Usage

Customer Costs

Rebates Paid

Administration Costs

Participation Levels
Replacement of standard small (from 5 to $50 \mathrm{hp}$ ) electrical motors with high-efficiency models.

Commercial/industrial.

Technology life is estimated to be approximately $20 \mathrm{yr}$.

For a 5-hp motor, the standard model would consume approximately $6,933 \mathrm{kWh} / \mathrm{yr}$, but an efficient model would consume only $6,413 \mathrm{kWh} / \mathrm{yr}$ (SERI 1991, vol. 2, p. 89). This savings is assumed to occur evenly over all hours of operation.

Additional customer costs will average $\$ 49 /$ motor (SERI 1991, vol. 2, p. 89).

Rebates equal to one-half the cost to the customer will be paid by the utility, or $\$ 25 /$ motor.

Incremental administrative costs for this program are assumed to be $\$ 1,000 /$ participant.

Initial population is assumed to be 10,000 customers with growth of $2 \% / y r$. Initial potential participation rate is assumed to be $1.5 \%$ with growth of 5\%/yr. Program participation is limited to 25 in first year, and growth is limited to 50 in second year and 75 in later years. A free rider rate is assumed to be $30 \%$. 


\section{A.2 COMMERCIAL/INDUSTRIAL HIGH-EFFICIENCY MOTORS - 50 HP}

Description

Rate Class

Technology Life

Energy Usage

Customer Costs

Rebates Paid

Administration Costs

Participation Levels
Replacement of standard large (over $50 \mathrm{hp}$ ) electrical motors with high-efficiency models.

Commercialindustrial.

Technology life is estimated to be approximately $20 \mathrm{yr}$.

For a 50-hp motor, the standard model would consume approximately $61,600 \mathrm{kWh} / \mathrm{yr}$, but an efficient model would consume only $58,520 \mathrm{kWh} / \mathrm{yr}$ (SERI 1991, vol. 2 , p. 89). This savings is assumed to occur evenly over all hours of operation.

Additional customer costs will average $\$ 270 /$ motor (SERI 1991, vol. 2, p. 89).

Rebates equal to one-half the cost to the customer will be paid by the utility, or $\$ 135 /$ motor.

Incremental administrative costs for this program are assumed to be $\$ 1,000 /$ participant.

Initial population is assumed to be 1,000 customers with growth of $2 \% / y$ r. Initial potential participation rate is assumed to be $20 \%$ with growth of $2.5 \% / y r$. Program participation is limited to 25 in first year, and growth is limited to 50 in second year and 75 in later years. A free rider rate is assumed to be $30 \%$. 


\section{A.3 COMMERCIAL LIGHTING - HIGH-EFFICIENCY FLUORESCENTS}

Description

Rate Class

Technology Life

Energy Usage

Customer Costs

Rebates Paid

Administration Costs

Participation Levels
Retrofit existing fluorescent lamps with high-efficiency lamps.

Commercial.

Technology life is estimated to be approximately 2 yr.

A 16.8\% energy savings is assumed to occur evenly over all hours of the year (SERI 1991, vol. 2, p. 54). An additional assumption was made that no secondary effect on heating or cooling occurs.

Additional customer costs will average $\$ 4.50 /$ amp (SERI 1991, vol. 2, p. 54); for four lamps per fixture and 20 fixtures per participant, the added cost is $\$ 360$.

Rebates equal to one-half the cost to the customer will be paid by the utility, or $\$ 180 /$ participant.

No incremental administrative costs for this program.

Initial commercial customer base in 1989 is 17,500 customers with growth of $2 \% / y x$. Population is growth in customer base plus 5\% of 1992 customer base each year. Initial potential participation rate is assumed to be $5 \%$ with growth of $2.5 \% / y r$. Program participation is limited to 50 in first year, and growth is limited to 100 in second year and 200 in later years. A free rider rate is assumed to be $30 \%$. 


\section{A.4 COMMERCIAL LIGHTING - ELECTRONIC BALLAST}

Description

Rate Class

Technology Life

Energy Usage

Customer Costs

Rebates Paid

Administration Costs

Participation Levels
Retrofit existing fluorescent lamps with electronic ballasts.

Commercial.

Technology life is estimated to be approximately $2 \mathrm{yr}$.

An energy savings of $26.6 \%$ is assumed to occur evenly over all hours of the year (SERI 1991, vol. 2, p. 54). An additional assumption was made that no secondary effect on heating or cooling occurs.

Additional customer costs will average \$66/fixture (SERI 1991, vol. 2, p. 54). For 20 fixtures per participant, the total cost will be $\$ 1,320$.

Rebates equal to one-half the cost to the customer will be paid by the utility, or $\$ 660 /$ participant.

No incremental administrative costs for this program.

Initial commercial customer base in 1989 was 17,500 customers with growth of $2 \% / y r$. Population is growth in customer base plus 5\% of 1992 customer base each year. Initial potential participation rate is assumed to be 5\% with growth of $2.5 \% / y r$. Program participation is limited to 50 in first year, and growth is limited to 100 in second year and 200 in later years. A free rider rate is assumed to be $30 \%$. 


\section{A.5 COMMERCIAL LIGHTING - LAMP REMOVAL AND REFLECTOR}

Description

Rate Class .

Technology Life

Energy Usage

Customer Costs

Rebates Paid

Administration Costs

Participation Levels
Retrofit existing fluorescent lighting by removing two lamps from each fixture and adding a reflector.

Commercial.

Technology life is estimated to be approximately $15 \mathrm{yr}$.

An energy savings of $52.2 \%$ is assumed to occur evenly over all hours of the year (SERI 1991, vol. 2, p. 54). An additional assumption was made that no secondary effect on heating or cooling occurs.

Additional customer costs will average $\$ 65 /$ fixture (SERI 1991, vol. 2, p. 54). For 20 fixtures per participant, the total cost will be $\$ 1,300$.

Rebates equal to one-half the cost to the customer will be paid by the utility, or $\$ 650 /$ participant.

No incremental administrative costs for this program.

Initial commercial customer base in 1989 is 17,500 customers with growth of $2 \% / y r$. Population is growth in customer base plus 5\% of 1992 customer base each year. Initial potential participation rate is assumed to be $5 \%$ with growth of $2.5 \% / y r$. Program participation is limited to $\mathbf{5 0}$ in first year, and growth is limited to 100 in second year and 200 in later years. A free rider rate is assumed to be $30 \%$. 


\section{A.6 RESIDENTIAL HIGH-EFFICIENCY AIR CONDITIONING}

Description

Rate Class

Technology Life

Energy Usage

Customer Costs

Rebates Paid

Administration Costs

Participation Levels
Replacement of a standard air conditioner with a high-efficiency model.

Residential.

Technology life is estimated to be approximately $15 \mathrm{yr}$.

For a 12 SEER system, an annual savings of $600 \mathrm{kWh}$ is assumed to occur evenly over all cooling hours of the year.

Additional customer costs will average $\$ 300$.

Rebates equal to one-half the cost to the customer will be paid by the utility, or $\$ 150 /$ participant.

Administrative costs for this program are assumed to be a onetime expense of $\$ 20 /$ participant.

Initial residential customer base in 1989 is 122,500 customers with growth of $2 \% / y r$. Population is the air conditioning customers (assuming a saturation rate of $75 \%$ in new construction and a saturation rate of $25 \%$ in 1992 existing buildings). Initial potential participation rate is assumed to be $40 \%$ with growth of $2.5 \% / y r$. Program participation is limited to 200 in first year, and growth is limited to 400 in second year and 800 in later years. A free rider rate is assumed to be $50 \%$. 


\section{A.7 RESIDENTIAL HIGH-EFFICIENCY CLOTHES DRYER}

Description

Rate Class

Technology Life

Energy Usage

Customer Costs

Rebates Paid

Administration Costs

Participation Levels
Replacement of a standard electric clothes dryer with a high-efficiency model.

Residential.

Technology life is estimated to be approximately $18 \mathrm{yr}$.

An annual savings of $124 \mathrm{kWh}$ is assumed for a standard unit used five times per week at $2.44 \mathrm{kWh}$ per use, for each of 52 weeks (SERI 1991, vol. 1, p. 107). This is assumed to occur evenly over all operating hours of the year.

Additional customer costs will average $\$ 75$ for the more efficient units (SERI 1991, vol. 1, p. 108).

Rebates equal to one-half the cost to the customer will be paid by the utility, or $\$ 37.50 /$ participant.

Administrative costs for this program are assumed to be a onetime expense of $\$ 20 /$ participant.

Initial residential customer base in 1989 is 122,500 customers with growth of $2 \% / y r$. Population is the electric clothes dryer customers (assuming a saturation rate of $75 \%$ in new construction and in 1992 existing buildings). Initial potential participation rate is assumed to be $25 \%$ with growth of $2.5 \% / y r$. Program participation is limited to 500 in first year, and growth is limited to 1,000 in second year and 3,000 in later years. A free rider rate is assumed to be $50 \%$. 


\section{A.8 RESIDENTIAL GROUND-SOURCE HEAT PUMP}

Description

Rate Class

Technology Life

Energy Usage

Customer Costs

Rebates Paid

Administration Costs

Participation Levels
Replacement of standard heating and air conditioning systems with a ground-source heat pump.

Residential.

Technology life is estimated to be approximately $15 \mathrm{yr}$.

Energy savings average $40.85 \%$, including heating and cooling savings (SERI 1991, vol. 1, p. 51).

Additional customer costs will average $\$ 2,380$ (SERI 1991, vol. 1, p. 51).

Rebates equal to one-half the cost to the customer will be paid by the utility, or $\$ 1,190 /$ participant.

Administrative costs for this program are assumed to be a onetime expense of $\$ 20 /$ participant.

Initial residential customer base in 1989 is 122,500 customers with growth of $2 \% / y r$. Population is the heat pump customers (assuming a saturation rate of $15 \%$ in new construction and in 1992 existing buildings). Initial potential participation rate is assumed to be $6.7 \%$. A free rider rate is assumed to be $50 \%$. 


\section{A.9 RESIDENTIAL AIR-SOURCE HEAT PUMP}

Description

Rate Class

Technology Life

Energy Usage

Customer Costs

Rebates Paid

Administration Costs

Participation Levels
Replacement of standard heating and air conditioning systems with an air-source heat pump.

Residential.

Technology life is estimated to be approximately $15 \mathrm{yr}$.

Energy savings average $24.4 \%$, including heating and cooling savings (SERI 1991, vol. 1, p. 51).

Additional customer costs will average $\$ 1,110$ (SERI 1991, vol. 1, p. 51).

Rebates equal to one-half the cost to the customer will be paid by the utility, or $\$ 555 /$ participant.

Administrative costs for this program are assumed to be a onetime expense of $\$ 20 /$ participant.

Initial residential customer base in 1989 is 122,500 customers with growth of $2 \% / y r$. Population is the heat pump customers (assuming a saturation rate of $15 \%$ in new construction and in 1992 existing buildings). The potential participation rate is assumed to be $100 \%$. A free rider rate is assumed to be $50 \%$. 


\section{A.10 RESIDENTIAL EFFICIENT LIGHTING}

Description

Rate Class

Technology Life

Energy Usage

Customer Costs

Rebates Paid

Administration Costs

Participation Levels
Replacement of incandescent lighting with compact fluorescents.

Residential.

Technology life is estimated to be approximately $7 \mathrm{yr}$.

An average savings of $166 \mathrm{kWh} / \mathrm{yr}$ is assumed to occur evenly over all hours of the year.

Additional customer costs will average $\$ 20 / \mathrm{bulb}$; at two bulbs per participant, total added costs are $\$ 40$.

Rebates equal to one-half the cost to the customer will be paid by the utility, or $\$ 20 /$ participant.

Administrative costs for this program were assumed to be a onetime expense of $\$ 3 /$ participant.

Initial residential customer base in 1989 is 122,500 customers with growth of $2 \% / y r$. Population is all residential customers. Initial potential participation rate is assumed to be $10 \%$ with growth of 5\%/yr. Program participation is limited to 5,000 in the first year and 10,000 in the second year. A free rider rate is assumed to be $30 \%$. 


\section{A.11 RESIDENTIAL HIGH-EFFICIENCY REFRIGERATOR}

Description

Rate Class

Technology Life

Energy Usage

Customer Costs

Rebates Paid

Administration Costs

Participation Levels
Replacement of a standard refrigerator with a high-efficiency model.

Residential.

Technology life is estimated to be approximately $20 \mathrm{yr}$.

An annual savings of $740 \mathrm{kWh}$ is assumed to occur evenly over all hours of the year (SERI 1991, vol. 1, p. 103).

Additional customer costs will average $\$ 136$ for the more efficient units (SERI 1991, vol. 1, p. 103).

Rebates equal to one-half the cost to the customer will be paid by the utility, or $\$ 68 /$ participant.

Administrative costs for this program were assumed to be a onetime expense of $\$ 20 /$ participant.

Initial residential customer base in 1989 is 122,500 customers with growth of $2 \% / y r$. Population is residential customers in new construction and in 5\% of 1992 existing housing. Initial potential participation rate is assumed to be $40 \%$ with growth of $2.5 \% / y r$. A free rider rate is assumed to be $75 \%$ (Saxonis 1991). 


\section{A.12 RESIDENTIAL - WATER HEATER INSULATION}

Description

Rate Class

Technology Life

Energy Usage

Customer Costs

Rebates Paid

Administration Costs

Participation Levels
Insulation of water heaters.

Residential.

Technology life is estimated to be approximately $13 \mathrm{yr}$.

An annual savings of $273 \mathrm{kWh}$ is assumed to occur evenly over all hours of the year (SERI 1991, vol. 1, pp. 76 and 82).

Additional customer costs will average $\$ 21$ (SERI 1991, vol. 1, p. 76).

Rebates equal to one-half the cost to the customer will be paid by the utility, or $\$ 10.50 /$ participant.

No administrative costs for this program.

Initial residential customer base in 1989 is 122,500 customers with growth of $2 \% / y r$. Population is all residential customers. Initial potential participation rate is assumed to be $10 \%$. A free rider rate is assumed to be $30 \%$. 


\section{A.13 RESIDENTIAL HIGH-EFFICIENCY CLOTHES WASHER}

Description

Rate Class

Technology Life

Energy Usage

Customer Costs

Rebates Paid

Administration Costs

Participation Levels
Replacement of a standard clothes washer with a high-efficiency model.

Residential.

Technology life is estimated to be approximately $15 \mathrm{yr}$.

An annual savings of $480 \mathrm{kWh}$ is assumed to occur evenly over all hours of the year (SERI 1991, vol. 1, p. 106).

Additional customer costs will average $\$ 150$ (SERI 1991, vol. 1, p. 76).

Rebates equal to one-half the cost to the customer will be paid by the utility, or $\$ 75 /$ participant.

Administrative costs for this program were assumed to be a onetime expense of $\$ 20 /$ participant.

Initial residential customer base in 1989 is 122,500 customers with growth of $2 \% / y r$. Population is the electric clothes dryer customers (assuming a saturation rate of $75 \%$ in new construction and in 1992 existing buildings). Initial potential participation rate is assumed to be $25 \%$ with growth of $2.5 \% / y r$. Program participation is limited to 500 in first year, and growth is limited to 1,000 in second year and 3,000 in later years. A free rider rate is assumed to be $50 \%$. 


\section{A.14 RESIDENTIAL AIR CONDITIONING DIRECT LOAD CONTROL}

Description

Rate Class

Technology Life

Energy Usage

Customer Costs

Rebates Paid

Administration Costs

Participation Levels
Direct load control of air conditioning units.

Residential.

Technology life is estimated to be approximately $15 \mathrm{yr}$.

The payback effect after the control period is assumed to offset energy savings.

No incremental customer costs.

No rebates issued.

No incremental administrative costs for this program. However, a capital expenditure of $\$ 100 /$ unit is required (SERI 1991, vol. 1 , p. 65).

Initial residential customer base in 1989 is 122,500 customers with growth of $2 \% / y r$. Population is the air conditioning customers (assuming a saturation rate of $75 \%$ in new construction and a saturation rate of $25 \%$ in 1992 existing buildings). Initial potential participation rate is assumed to be $40 \%$ with growth of $2.5 \% / \mathrm{yr}$. Program participation is limited to 200 in first year, and growth is limited to 400 in second year and 800 in later years. No free riders are possible in this program. 


\section{A.15 RESIDENTLAL WEATHERIZATION}

Description

Rate Class

Technology Life

Energy Usage

Customer Costs

Rebates Paid

Administration Costs

Participation Levels
Retrofit existing residences with additional building energy conservation measures.

Residential.

Technology life is estimated to be approximately $30 \mathrm{yr}$.

An average savings level of $7 \%$ is assumed to occur evenly over all hours in the year (Butteroff 1992).

Additional customer costs will average $\$ 575$, assuming an average home size of $1,000 \mathrm{ft}^{2}$ (Butteroff 1992).

Rebates equal to one-half the cost to the customer will be paid by the utility, or $\$ 287.50 /$ participant.

Administrative costs for this program are assumed to be a onetime expense of $\$ 500 /$ participant.

Initial residential customer base in 1989 is 122,500 customers with growth of $2 \% / y r$. Population is all residential customers. Initial potential participation rate is assumed to be $10 \%$. A free rider rate is assumed to be $30 \%$. 


\section{A.16 AGRICULTURAL IRRIGATION}

Description

Rate Class

Technology Life

Energy Usage

Customer Costs

Rebates Paid

Administration Costs

Participation Levels
Installation of high-efficiency pumping plant system. Agricultural.

Technology life is estimated to be approximately $20 \mathrm{yr}$.

Annual energy savings of $140,400 \mathrm{kWh}$ given the following (SERI 1991, vol. 3, pp. 16-19):

- Twenty-four hour usage of pumping systems May through August;

- Irrigation water usage of 1,500 acre-ft/yr;

- Pre-DSM pumping system efficiency of 50\%;

- Water lift of $200 \mathrm{ft}$;

- Delivery pressure of $60 \mathrm{psi}$; and

- Post-DSM pumping system efficiency of $65 \%$.

Additional customer costs will average $\$ 200$ per efficiency test, with one test conducted per year on an average of ten pumps per participant (SERI 1991, vol. 3, p. 18). Total incremental costs will be $\$ 2,000$.

Rebates equal to one-half the cost to the customer will be paid by the utility, or $\$ 1,000$ per participant.

No incremental administrative costs for this program.

Participation level is assumed to be 25 new participants per year for the first four years, beginning in 1993. A free rider rate is assumed to be $50 \%$. 


\section{A.17 DAIRY REFRIGERATION — WASTE HEAT RECOVERY}

Description

Rate Class

Technology Life

Energy Usage

Customer Costs

Rebates Paid

Administration Costs

Participation Levels
Recovery of waste heat from refrigeration equipment for water heating purposes.

Agricultural.

Technology life is estimated to be approximately $20 \mathrm{yr}$.

For a typical dairy operation producing $20,000 \mathrm{lb} / \mathrm{d}$ of milk, an annual energy savings of $4,886 \mathrm{kWh}$ is assumed to occur evenly over all hours of the year (SERI 1991, vol. 3, p. 35).

Additional customer costs will average $\$ 4,538$ (SERI 1991, vol. 3, p. 35).

Rebates equal to one-half the cost to the customer will be paid by the utility, or $\$ 2,269 /$ participant.

No incremental administrative costs for this program.

Participation level is assumed to be 25 new participants per year for the first four years, beginning in 1993. No free riders are assumed. 


\section{A.18 EARTH-TUBE HEAT EXCHANGE VENTILATION SYSTEM}

Description

Rate Class

Technology Life

Energy Usage

Customer Costs

Rebates Paid

Administration Costs

Participation Levels
An underground heat exchanger makes use of the relatively constant temperatures below ground to cool incoming air in the summer and to warm incoming air in the winter. In this case, the heat exchanger is applied in livestock confinement structures.

Agricultural.

Technology life is estimated to be approximately $20 \mathrm{yr}$.

For a typical livestock operation consisting of 50 animals, an annual energy savings of $24,800 \mathrm{Wh}$ is assumed to occur over the peak heating and cooling days of the year (SERI 1991, vol. 3, p. 70).

Additional customer costs will average $\$ 150$ per animal for a total of $\$ 7,500$ (SERI 1991, vol. 3, p. 35).

Rebates equal to one-half the cost to the customer will be paid by the utility, or $\$ 3 ; 750 /$ participant.

No incremental administrative costs for this program.

Participation level is assumed to be 25 new participants per year for the first four years, beginning in 1993. No free riders are assumed. 


\section{A.19 REFERENCES FOR THE APPENDIX}

Butteroff, L., 1992, personal communication from Butteroff (Stone and Webster Management Consultants, Denver, Colo.) to J. Cavallo (Argonne National Laboratory, Argonne, Mll.), Oct. 21.

Saxonis, W., 1991, Handbook of Evaluation of Utility DSM Programs, Chapter 8, ORNL/CON-336, E. Hirst and J. Reed (editors), Oak Ridge National Laboratory, Oak Ridge, Tenn., p. 119.

SERI, 1991, DSM Pocket Handbook, SERI/TP-254-409098, Solar Energy Research Institute, Golden, Colo., April. 


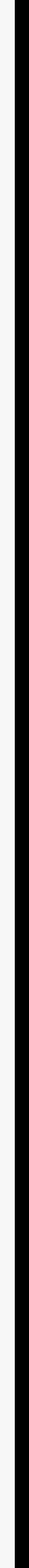




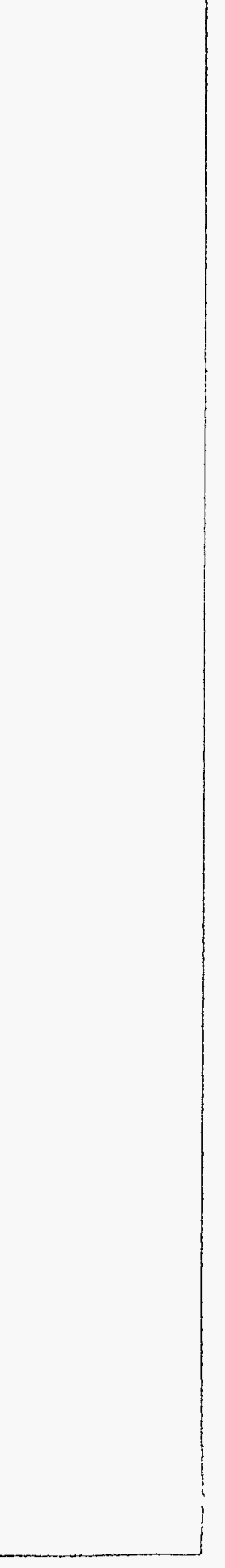




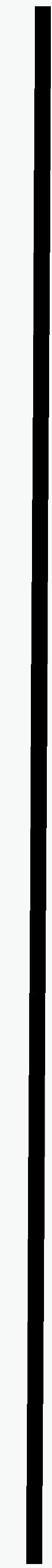

